\title{
PERIODIZATION MODELS IN THE RESEARCH OF THE MUSCLE STRENGTH IN ATHLETES, THEORETICAL-METHODOLOGICAL REDUCTIONS OR NON-CRITICAL POSITIVISM IN SPORT-SCIENTIFIC PERIODICS
}

\section{LOS MODELOS DE PERIODIZACIÓN EN LAS INVESTIGACIONES DE LA FUERZA DE MÚSCULOS EN LOS DEPORTISTAS, LAS REDUCCIONES TEÓRICO-METODOLÓGICAS O EL POSITIVISMO NO CRÍTICO EN LAS PUBLICACIONES DEPORTIVO-CIENTÍFICAS}

\author{
Marko Cosic \\ Faculty of Sports and Physical Education, University of Belgrade, Serbia
}

\section{ABSTRACT}

Periodization is a theoretical and practical construct of sports training that relates to the programming of training activities in mutually dependent periods of time in order to induce specific physiological adaptations. During training and competition processes, it is used to achieve results at the specific competition. The theoretical and practical foundations of the periodization process can also be studied from the aspect of its impact on biomotor abilities. In this context, the general position for the study of periodization include research covering the impact of different periodization models on muscle strength (the subject of this paper). Based on an analysis of the content, meaning, methodological orientation, and conclusion within a selected number of published studies/papers, it cannot be ascertained whether periodized training models, in the muscle strength area, give better results than the non-periodized model, or which periodized model gives better results at all. The above-mentioned dilemmas regarding the subject of this work have also been confirmed in several review papers and meta-analyses. However, by examining the methodological and theoretical context of these studies, a number of dilemmas are evident, primarily those related to the sample of the subjects. Namely, none of the analyzed studies focused only on the athletes as a target group, but instead, the results of the research performed on athletes were analyzed in relation to a group of recreational or nontrained subjects. Also, there is a discrepancy in the terminology of the applied periodization models, which opens up the question regarding the existence of a clear theoretical concept and methodological-organizational construct that aims to achieve
\end{abstract}

\begin{abstract}
EXTRACTO
La periodización es un constructo teórico y práctico de entrenamiento deportivo que se refiere a la programación de actividades de entrenamiento en los períodos de tiempo interdependiente, para provocar las adaptaciones fisiológicas específicas. En el proceso de entrenamiento y de competencia se utiliza en función de lograr resultados en la competencia objetivo. La base teórica y práctica del proceso de periodización puede, entre lo demás, estudiarse también desde el aspecto de su influencia en las capacidades biométricos. En tal contexto, lo general en el estudio de la periodización son las investigaciones que se refieren a la influencia de distintos modelos de periodización en la fuerza de músculos (objetivo del presente trabajo). Sobre la base de análisis del contenido, sentido, orientación metodológica y conclusiones dentro de un número seleccionado de investigaciones publicadas (método cognitivo), no se puede afirmar con seguridad si los modelos periodizados de entrenamiento en el segmento de la fuerza muscular dan mejores resultados que los modelos no periodizados, como tampoco, ¿qué modelo de los modelos periodizados da mejores resultado en ese sentido? Los dilemas mencionados del objeto del presente trabajo han sido confirmados también en algunos trabajos y meta-análisis revisados. Sin embargo, por la revisión del contexto metodológico y teórico de esos estudios, se nota un mayor número de dilemas, ante todo aquel referido a la muestra de examinados. Es decir, ninguno de los estudios analizados no ha tenido en su enfoque solo los deportistas como el grupo objetivo, sino los resultados de las investigaciones realizadas en los deportistas se analizaron en relación con el grupo de atletas recreativos o en relación con los examinados no entrenados. Se nota, también, la inconsistencia
\end{abstract}


a competitive result. It can be assumend that a clear analysis of the original context of the phenomenon of periodization, harmonization of methodical and methodological steps in the process of learning, clear distinction towards existing definitions and terminology, resulted in the optimization of the learning process that will lead to recognition of the periodization model, which will result in optimization of the training-competitive preparations goals. Therefore, the problem of this paper derived from the theoretical and methodological inconsistency of the researchers in areas covering the influence of different periodization models on athletes' strength. The aim of the paper was to analyze and determine the facts of the methodological and theoretical construct of periodization, the conclusions of various studies, which can be said to - despite publication in important international journals - lead to confusion in the area of the conclusion about the influence of different periodization models on the strength of athletes. After examining more than 80 papers published in refereed journals, and by selection in relation to the theoretical-methodological context and the context of deductive conclusions, 10 studies have been selected, in which the influence of different periodization models on the strength of athletes, while performing exercises with arms and legs, were compared. The results indicate that the applied periodized models, especially the block model, showed a higher degree of sensitivity towards the development of athletes' strength, but several important questions were also raised regarding the validity of the conclusions on this subject. However, the outcome and the purpose of this research is to present a more comprehensible definition of the periodization phenomenon and its models, as well as to identify the effects of the experimental factor in the function of the biomotor response of the subjects to the training stimuli.

Keywords: PERIODIZATION / MUSCLE STRENGTH / COGNITIVE PARADIGM / METHODOLOGICAL INCONSISTENCY / SPORT-SCIENTIFIC PERIODICS en la terminología de modelos de periodización aplicados, con lo que surge la pregunta de la existencia de un concepto teórico y de un constructo metódico-organizativo claros, con los que se planifica el logro del resultado competitivo. Se supone que por un análisis claro del contexto original del fenómeno de periodización, armonización de los pasos metódicos y metodológicos en el proceso de cognición, una clara distinción de las definiciones y terminología existentes, se llegaría también a la optimización del proceso de cognición que llevaría hacia el reconocimiento del modelo de periodización que conducirá hasta los objetivos óptimos de la preparación de entrenamiento-competencia. Por lo tanto, el problema de la presente investigación surgió de la inconsistencia teórica y metodológica de los investigadores en el espacio de influencia de los distintos modelos de periodización en la fuerza de deportistas. El objetivo del trabajo es entender, a través de análisis y establecimiento de hechos del constructo metodológico y teórico de periodización, las conclusiones de distintas investigaciones para las que se puede decir que - a pesar de la publicación en las importantes revistas internacionales conducen a la confusión en el espacio de conclusiones sobre la influencia de distintos modelos de periodización en la fuerza en los deportistas. Después de revisar más de 80 trabajos publicados en las revistas de referencia, con la selección en relación con el contexto teórico-metodológico y contexto de conclusión por deducción, por este análisis se han separado las 10 investigaciones en las que se compara la influencia de la aplicación de distintos modelos de periodización en la fuerza en los deportistas manifestada al hacer ejercicios con los brazos y piernas. Los resultados indican que los modelos periodizados aplicados, ante todo el bloque, mostraron un mayor nivel de sensibilidad en el desarrollo de la fuerza en los deportistas, pero también han surgido algunas preguntas importantes referentes precisamente a la validez de las conclusiones sobre este tema. Sea como sea, el resultado y la conveniencia de la presente investigación deben observarse como una definición más clara del fenómeno de periodización y de sus modelos, y reconocer también el efecto del factor experimental en función de la respuesta biomotriz de los examinados a los estímulos de entrenamiento.

Palabras claves: PERIODIZACIÓN / FUERZA MUSCULAR / PARADIGMA DE COGNICIÓN / REDUCCIÓN METODOLÓGICA / PUBLICACIONES CIENTÍFICAS

\section{INTRODUCTION}

Periodization is a theoretical and practical construct that is based on the logical, methodological, methodical and systematic process of planning training activities as a unique whole that leads to biomotor and psychic benefits in order to achieve peak training-competitive form at the appropriate time points. In other words, it is programming of training interventions in mutually dependent periods of time in order to induce specific physiological adaptations in the function of achieving results (Haff \& Triplett, 2015). In a broader context, the goal is to have an overall transformation of the performance attributes, that is, integrate optimization of all the potentials of the ath- lete's for the performance at a specific competition. Besides the fact that periodization creates preconditions to ensure that the sporting form is achieved at the major competition, its methodological and cognitive context can, and must be studied also from the position of the overall impact on the biomotor abilities (speed, strength, power, agility and endurance) (Bompa \& Haff, 2009). So, in a narrow context, periodization refers to the structuring of the training stages in order to bring the psychomotor abilities to the desired level, according to which this paper is referring to. 


\section{PERIODIZATION - CHALLENGES AND CONCERNS OF RESEARCH PROTOCOLS}

To date, sports practice and exercising have created a great number of variations of the training organization process that have grown into models - theoretical and practical constructs - and which, in relation to the subject of this paper, can be divided into non-periodized and periodized. The problems of unfinished training-competitive practice are compounded by the use of different terminology (semantic uncertainty) which, unfortunately, is more noticeable in scientific journals in relation to work in immediate practice. In short, research processes are implemented on the basis of insufficiently defined criteria for the classification of processes that accompany periodization. After analyzing the published papers, it remains unclear whether the periodization process is an essential or formal criterion for biomotor adaptation, i.e. are the supercompensation process and the setting of deload training periods the through the changes of some training load variables the only effects that ensures the integration of cumulative training effects in the construction of the competitive result?

In the process of scientific uncovering of the periodized training phenomenon and its effects, a nonperiodized (NP) experimental factor is used. The methodological settings of this experimental factor (exercise) are set in relation to uniform, linear and random variant of periodization (Strohacker, Fazzino, Breslin, \& Xu, 2015). However, in a comprehensive and up-to-date research design, only random and uniform variants should be classified in this experimental exercise group, which includes tracking unsystematic changes in their volume and/or intensity, or constant values of volume and intensity during the training period. In relation to muscle strength, this should be indicated by the number of repetitions and the percentage of one repetition maximum (1RM). For convenient purpose of such an approach the experimental design should be sought in the absence of any biomotor cycles in the process of training adaptations, so therefore, periodization cannot be discussed in its original theoretical and practical meaning.

Bearing in mind that periodization implies load variation in order to facilitate the integration of planned exercises and fatigue caused by training in terms of progressive flow adaptation (DeWeese, Gray,
Sams, Scruggs, \& Serrano, 2013), in this context - in the experimental design - linear variant of training load should also be classified into non-periodized model, since variation of load is not only implied by the change in the value of some load variables (where one increases and the other decreases), but above all the variation of the total amount of load that leads to cumulative training-competitive effects. It is true that linear variants (progressive and reverse) accompany changes in volume and intensity during periods of training which occurs in cycles (usually in 2, 3 or 4 weeks), but it is also true that these variants are not followed by the deload period, thus eliminating wave-like loading in the true sense of the word, which is one of the prerequisites for the creation of the middle cycles of training - mesocycles. But, given the frequent use of the experimental factor through the linear training load, for the purposes of this paper it will be considered like a periodized model. Additional confusion is created in the analyzed papers when certain authors named this model a traditional one (Ullrich, Pelzer, \& Pfeiffer, 2018; Ullrich, Pelzer, Oliveira, and Pfeiffer, 2016), or traditionally linearly periodized (Hoffman, Ratamess, Klatt, Faigenbaum, Ross, Tranchina, ... \& Kraemer, 2009), although these models do not have deload periods (which is the fundamental characteristic of the traditional model). On the other hand, there are also cases where authors define periodization models as a non-periodized, linear and nonlinear, although the analysis of all three observed models showed that they had periods of increased load (3 weeks) and deload (1 week) (Monteiro, Aoki, Evangelista, Alveno, Monteiro, da CruzPiçarro, \& Ugrinowitsch, 2009), which would define them as variants of the traditional model.

In addition to the models without cyclical changes in the load variables, there are some periodized models in which these cycles exist in a certain sense. These models are characterized by changes in load variables, where different variations occur in relation to the purpose, frequency and magnitude of these changes. For the purposes of this paper, the following periodization models and their variations will be considered as periodized models:

- Linear Periodization Model (LP);

- Traditional Periodization Model (TP);

- Block Periodization Model (BP).

- Undulating Periodization Model (UP);

The LP primarily refers to its progressive variant (the intensity is progressively increasing) character- 
ized by a high volume and low intensity work at the beginning of the training program. Over time, load variables are changing, volume decreases gradually, while intensity increases. The second variant of the training program that involves low-volume and highintensity work at the beginning of the program, where over time the volume gradually increases as the intensity decreases, is also considered the LP. This variant is called the reverse linear periodization model and is suitable for the development of muscular endurance and maximum strength (Clemente-Suárez, Fernandes, Arroyo-Toledo, Figueiredo, González-Ravé, and Vilas-Boas, 2015), where it is important to monitor and analyze the residual effects of power parameters.

The TP is characterized by wave-like progression, i.e. periods of overload ${ }^{1)}$ intercepted by deload periods, where the exercise at the beginning of the program coincides with the phase of general preparation. It is characterized by high volume and low intensity of training load, which later (the phase of specific preparation) changes and directs to low volume and high intensity (Kraemer \& Ratamess, 2004). It is similar to LP, but unlike it, there are periods of deload (it forms the foundation for the existence of mesocycles) and is therefore termed TP (Strohacker et al., 2015). In practice, there is no confusion about this training program and its terminology. It is a widespread and applicable periodization model that came from a clearly defined theory to which this model belongs.

The BP is a training program that's implemented in blocks (Accumulation-Transformation-Realization) in which the focus is on specific goals. The middle cycles of training (blocks) are specific characteristic of the BP as a separate concept of periodization (Issurin, 2009), and for this reason, there is no confusion about the classification and terminology in this model either.

The UP is characterized by more frequent change in the load variables than in the TP, but without changing the total amount of load (deload periods) during the training program. In relation to their frequency, there are several variants of this model. The daily undulating variant (DUP) is the most frequent, characterized by different volumes and intensities within

\footnotetext{
1) Overload refers to assigning a training regime of greater load than the athlete is accustomed to (Baechle \& Earle, 2008). Primarily in terms of stimulating load - or a combination of retaining and stimulating load; load that is not inadequate, i.e. it is not overreaching that leads to overtraining.
}

each individual training session or week. Weekly undulating variant (WUP) is characterized by changes in volume and intensity on a weekly or a two-week (2WUP) level. Also, it is possible to combine some variants of the undulating models - a daily and weekly variant - where each training session in a week involves a different program, but every week is different from the previous week. In practice (wrong) it is classified as one of the already existing variants of the UP. In the design of some research, in their very experimental factor, there is a clear difference between the 2WUP and the LP, which changes the load on every two weeks (Tammam \& Hashem, 2016). Namely, the correctness in the setting of the experimental factor arises from a more sensitive approach to the effects of LP that take place in one direction of the relationship of the load variables (e.g. the volume is constantly decreasing and the intensity is constantly increasing), while in the 2WUP this relationship also changes every 2 weeks, but not always in the same direction. Non-linear periodization model (NLP) is practically one of the variants of the undulating approach to training loads. Although it is often distinguished as a separate (problem of terminology), for the purposes of this analysis, it will be defined as UP (Hoffman et al., 2009; Kraemer, Häkkinen, Triplett-McBride, Fry, Koziris, Ratamess, ... \& Gordon, 2003). Flexible nonlinear periodization model (FNLP) is another variant of the UP. It is characterized by the adaptability of the training activities based on the readiness of the athlete and by the outward appearance of the periodized work is very similar to the DUP. Therefore, for the purpose of easier understanding of their impact, all these periodization models of training load will be treated as variants of UP, which they are in their essence.

Bearing in mind that periodization implies the effect of training, based on its phases and periods of its impact, it is obvious that periodization cannot be linear or undulating (Bompa \& Buzzichelli, 2018). It can be noticed that only TP and BP can be considered as a periodized models in the true sense of the word in terms of changing the total amount of load, as well as the existence of medium cycles. In this context, these two models have no confusion about terminology. The great inconsistency in the terminology that leads to the error in the setting of the experimental factor and the conclusion based on the results of the research models arises precisely because the models are called according to the shape or outward appearance of the periodized work. In contrast, the es- 
sence of research projects should be the structure or internal appearance of the variation of training load and recovery. In particular, in case of the uniform and random (non-periodized) models, and also in the LP and UP (for this research they are classified into periodized models, although they are practically non-periodized), the essence - even the name - is in the external appearance, while in TP and BP this is certainly the internal structure and variation of the training load and recovery. However, in this paper, only random and uniform models will be considered as non-periodized models, while TP and BP, as well as LP and UP, will be considered as periodized models.

\section{Strength and power in the theory of sports training}

The professional and scientific community has been debating for a long time about the most appropriate way to improve strength and power. To this end, they were investigating the influence of various periodization models on different motor abilities and characteristics of subjects with different chronological and training age, as well as the degree of training. Although the prevailing opinion is that the application of periodized models is better when aiming at developing strength, power and muscular endurance with respect to non-periodized model (Fleck, 1999; Herrick\& Stone, 1996; Kramer, Stone, O’bryant, Conley, Johnson, Nieman, ... \& Hoke, 1997; O’bryant, Byrd, \& Stone, 1988; Rhea \& Alderman, 2004; Stone, Potteiger, Pierce, Proulx, O'bryant, Johnson, \& Stone, 2000; Williams, Tolusso, Fedewa, \& Esco, 2017), certain studies suggest that the benefits of periodization with the goal of developing muscular strength and hypertrophy are largely based on assumptions, and have little solid evidence that periodization is a superior exercising plan (Mattocks, Dankel, Buckner, Jessee, Counts, Mouser, ... \& Loenneke, 2016). It is also concluded that when the total volume and intensity of the load are equalized, then there is no difference in the application of the non-periodized and the periodized model (Baker, Wilson, \& Carlyon, 1994), i.e. that the periodized model does not always lead to significant improvements compared to the non-periodized model (Grgic, Lazinica, Mikulic, \& Schoenfeld, 2018; Hoffman et al., 2009; Souza, Ugrinowitsch, Tricoli, Roschel, Lowery, Aihara, ... \& Wilson, 2014). In other words, it is not necessarily disputed that periodized models are superior (the existence of a methodological explanation to vary training vari- ables in order to optimize outcomes), but in view of the above-mentioned limitations of the experimental factor, it is obvious that, based on previous research, it is not possible to draw relevant and valid conclusions related to this topic (Nunes, Ribeiro, Schoenfeld, \& Cyrino, 2018). The inconsistency in the conclusions is also found in studies in which different variants of periodized training were compared, primarily the linear and the undulating periodization model, and in which it was concluded that there was no difference between the mentioned exercising models (or periodization?) (Buford, Rossi, Smith, \& Warren, 2007; Harries, Lubans, \& Callister, 2015; Grgic, Mikulic, Podnar \& Pedisic, 2017). It is not possible to conclude from the analysis whether the researchers, with the design of their research, tend to determine if there is a difference in the effects between the traditional and the undulating periodization model on the observed biomotor abilities, primarily on the muscle strength. It is not possible to determine which periodized program model of the experimental factor is more effective, since the conclusions of some previous studies, to which the authors call, showed that the undulating model is better for the development of strength (assessed through 1RM), but not for power, muscular endurance, isometric strength, and muscle hypertrophy (Caldas, Guimarães-Ferreira, Duncan, Leopoldo, Leopoldo, \& Lunz, 2016).

The lack of a unified opinion on the theoretical and practical context of periodization leads to inconsistent conclusions about the effectiveness of different periodization models, which are most likely and primarily based on errors in the methodology used in various researches. Namely, after reviewing the research, covered by meta-analyses and by additional insight into the realized training programs within them, a presence of certain inconsistency was observed in the names of the periodization models. For this reason, if the models are to be compared essentially, and not by the names assigned by their authors, it could be assumed that more concrete conclusions would be obtained (differently defined periodization models, specificity of training loads, different amount of some load variables). The next, not so insignificant factor that determines possible errors in the conclusion by the experimental factor is the small sample and the small homogeneity of the subjects in terms of different criteria (gender, age, lifestyle, degree of training, training history). Bearing in mind the specificity of the training and the impact of changing the exercise methods on adaptation, as well as the differ- 
ent duration of experimental factors, it is assumed that with different groups of subjects the response of the organism will be different as well. In particular, if it is assumed that in sports practice the traditional periodization model is more utilized than some other models, as confirmed in one study that has addressed with this topic (Junior \& Drigo, 2017), it will be in an unequal position in relation to models which were not previously applied to the observed athletes. It is therefore very difficult to make a unique conclusion about the size of the impact of a particular periodization model in relation to the other. The suggestion is that future studies should control the application of the principle regarding exercise effects specificity, as well as other variables by which the sporting form is built. It would be possible to correctly determine whether the systematic load variation is important for maximizing the observed motor abilities. This is supported by the conclusions of almost all analyzed studies, which is the need for further research (Miranda, Simão, Rhea, Bunker, Prestes, Leite, ... \& Novaes, 2011; Moraes, Fleck, Dias, \& Simão, 2013; Rhea \& Alderman, 2004 Silva, Vilação-Alves, de Souza, dos Santos, \& Figueiredo, 2016; Storer, Dolezal, Berenc, Timmins, \& Cooper, 2014). The question is whether the final testimony of empirical efforts for the need of future research is caused either by, the expression of methodological inconsistency, insufficient theoretical and practical enlightenment of the researchers, the insufficient structure of research teams in terms of covering all areas of sports science, or insufficiently throughout research problem? If the answer is the last one of the just mentioned concerns, this raises the question of the relevance of the research, and therefore the process of concluding by the subject and the problem!

These deficiencies could be partially solved by looking at the essential characteristics of the exercise program (no matter how the researchers defined it), but also by the specific homogenization of the sample, that is, by examining the impact of different periodization models on subjects which are homogenized according to some criteria.

The problem of this research came from the observed theoretical and methodological inconsistency of the researchers in the area of the study design, and the discussion on the influence of different periodization models on the strength of athletes. The subject of the paper includes published studies that focused on the impact of the application of different periodization models on the strength of trained athletes. The aim of the paper was to analyze and determine the facts of the methodological and theoretical construct of periodization, as well as to understand the conclusions of various researches, for which one can say that - in addition to their publications in important international journals - they lead to confusion in the area of conclusion about the influence of different periodization models on the strength of athletes. The research tasks were: searching electronic databases, reviewing and organizing the collected research, defining the basic characteristics of the training programs, and theoretical and analysis of the meaning of the studies design and their results.

\section{METHOD}

\section{Sample of studies}

Only those studies that compared the impact of the influence of different periodization models to the strength of athletes were taken into consideration. Electronic search of papers was carried out in the following databases: PubMed, ScienceDirect, SCIndex and Google Scholar. The search was carried out by a combination of key words related to periodization, strength training, and athletes. The search was limited to the following terms in English: "periodization", "strength", "power", "resistance", "sport”, “athletes", "training", "exercise", "effects", "volume", "intensity", "load", "comparison", "influence", and "performance". 84 papers published in scientific journals classified on the SCI list in the period from 2003 to 2018 have been collected and reviewed.

\section{Selection of variables - discrimination of analyzed research studies}

In the research studies, within the specificity of different sports in which athletes train and compete, different motor abilities, muscular stress and adaptation characteristics (isometric force, strength, power, explosive power, and hypertrophy) were assessed. Also, in the process of arriving at conclusions on the subject of design, various tests were applied and the flow of research studies was accompanied by various data collection techniques. Bearing in mind that the suggestion about the need for new research is in almost all analyzed studies, for this research a selec- 
tion was made of studies that contain clear data of variables and were presented in such a way that they can be unambiguously compared. In other words, a step forward in understanding the meaning of analyzed studies has been made, with the aim of correcting methodological and terminological reductions of previous researches. In accordance with the subject of this paper, researches has been selected in which load variables are clearly defined, as well as variables that describe the strength of the subjects - maximum isometric force and/or 1RM. Also, in selecting the experimental influence of the selected exercises, the criterion was that the exercises were relatively simple and widespread in the strength training of athletes. In this regard, for the assessment of the effects of the experimental factors on the muscles of the arm, bench press was selected, while for the leg muscles, two multi-joint exercises were selected: squats (different knee angles) and the legs press, as well as two singlejoint exercises: leg extension and leg curl.

\section{Classification criteria}

After analyzing more than 80 papers published in refereed journals, selecting them in relation to the theoretical-methodological context and the context of deductive conclusions, 10 of them have been singled out in which the influence of different periodization models (through training with jumps, free weights or weight machines) on the strength of athletes, through arms and/or legs exercises was compared. These papers were controlled randomized and non-randomized studies with only athletes as subjects. In them, the application of different periodization models lasted for at least 4 weeks, without discussion - for now - about the fundamental question: can the analyzed exercise models in this case be called periodization models at all? Also, the results of only those studies in which the training program was clearly defined during the experimental period (objectivity, verifiability) were taken into account.

Out of 84 analyzed, the aforementioned criteria was only met by 10 published researches: Manchado et al. (Manchado, Cortell-Tormo, \& Tortosa-Martínez, 2018), Ullrich et al. (2018), Tammam and Hashem (Tammam \& Hashem, 2016), Ullrich et al. (2016), Franchini et al. (Franchini, Branco, Agostinho, Calmet, \& Candau, 2015), Bartolomei et al. (Bartolomei, Hoffman, Merni, \& Stout, 2014), Painter et al. (Painter, Haff, Ramsey, McBride, Triplett, Sands, ... \& Stone, 2012), Hoffman et al. (2009), Hoffman et al. (Hoffman,
Wendell, Cooper, \& Kang, 2003), as well as Kraemer et al. (2003). In them, a total of 229 subjects (168 men and 61 women) completed the research. The influence of different periodization models was assessed, most often through the 1RM test, and in some cases also through the maximum voluntary isometric contraction. Different periodization models monitored by tests which were simple exercises performed on isokinetic machines, weight machines or with free weights, and they were: bench press (in 8 studies), squat (5), half squat (3; one in isometric contraction), leg press (1), leg extension (3; two times in isometric contraction), as well as leg curls (2; one time in isometric contraction). However, in the theoretical sense, most papers showed reductions, because only 4 analyzed papers included names of the applied periodization models, and therefore the planned outcomes of the training were in accordance with the attached training program. In other words, theoretical reductions lead to methodological reductions, and hence to the disputability of the results and conclusions of the research, whose subject is to monitor the effects of the periodized exercising. This is due to the use of inaccurate names, or variants of some models, or even periodization models. Discussion chapter presents concrete training programs as well as the reasons for classifying applied periodization variants, i.e. models into another variant, i.e. model.

\section{RESULTS}

The results of this study indicate that from five observed models (non-periodized, linear, traditional, block, undulating), the block periodization model proved to be potentially the best solution for development of the athletes' strength. Namely, in a study of Bartolomei et al. (2014), as well as Manchado et al. (2018), block model was compared with the traditional model and proved to be a better solution for strengthening the arms, while for the legs there was no difference. On the other hand, in research by Painter et al. (2012) the block model was compared with the undulating model and proved to be a better solution for strengthening the leg muscles. As for the linear and the undulating model, four studies have found that both models have an effect in terms of improving abilities (Franchini et al., 2015; Tammam \& Hashem, 2016; Ullrich et al., 2018; Ullrich et al., 2016), while in one of them, the undulating model has also proven to be a significantly better solution 
(Tammam \& Hashem, 2016). Two studies have compared the undulating model and non-periodized model. In one, there is no difference, and the conclusion is that both models equally improve the abilities of both arms and legs (Kraemer et al., 2003), while in the other, non-periodized model gives better results in the legs, while in the arms none of the models show improvements (Hoffman et al. al., 2003). In one study, the undulating, non-linear, and the linear model were compared, and the conclusion is that all observed models influence the improvement of legs and arms strength (Hoffman et al., 2009). Significant differences were not noticed between the observed models. Table 1 shows an overview of all 10 selected studies.

Table 1. An overview of the impact of different periodization models on the strength in athletes.

\begin{tabular}{|c|c|c|c|c|}
\hline Study & $\begin{array}{l}\text { Subjects, duration, } \\
\text { sport }\end{array}$ & Observed variables & $\begin{array}{l}\text { Comparing } \\
\text { periodization models } \\
\text { (and the name of the } \\
\text { model before reduction) }\end{array}$ & Conclusion \\
\hline $\begin{array}{l}\text { Manchado } \\
\text { et al. (2018) }\end{array}$ & $\begin{array}{l}\text { - } \mathrm{N}=11 \text {, woman } \\
\text { - Handball } \\
\text { - } 16 \text { weeks, } 2 \text { x per week }\end{array}$ & $\begin{array}{l}\text {-1RM bench press } \\
\text {-1RM half squat }\end{array}$ & BP vs TP & $\begin{array}{l}\text { BP proved to be a better solution for the } \\
\text { development of the strength of the arms, } \\
\text { while there is no difference in the legs. }\end{array}$ \\
\hline $\begin{array}{l}\text { Ullrich } \\
\text { et al. (2018) }\end{array}$ & $\begin{array}{l}\text { - } \mathrm{N}=22,12 \text { men \& } 10 \\
\text { women } \\
\text { - Different sports } \\
\text { - } 6 \text { weeks, } 3 \text { x per week }\end{array}$ & $\begin{array}{l}\text { - Isometric leg } \\
\text { extension } \\
70^{\circ} / 90^{\circ} / 110^{\circ}\end{array}$ & $\begin{array}{l}\text { LP vs UP } \\
\text { (TP vs DUP) }\end{array}$ & $\begin{array}{l}\text { Both models are equally effective to } \\
\text { increase the leg extensors strength. } \\
\text { Jumps (CMJ) with different loads ( } 0 \% \text {, } \\
\text { 15\%, 30\% of body weight) were used as } \\
\text { a power development tool. }\end{array}$ \\
\hline $\begin{array}{l}\text { Tammam } \\
\text { \& Hashem } \\
(2016)\end{array}$ & $\begin{array}{l}\cdot \mathrm{N}=16 \text {, men } \\
\cdot \text { Volleyball } \\
\cdot 12 \text { weeks, } 4 \text { x per week }\end{array}$ & $\begin{array}{l}\text {-1RM bench press } \\
\text {-1RM half squat } \\
\text {-1RM leg curl } \\
\text {-1RM leg extension }\end{array}$ & • LP vs UP & $\begin{array}{l}\text { After } 12 \text { weeks, significant progress } \\
\text { was observed with both models. Also, } \\
\text { UP is significantly more effective in } \\
\text { all observed variables compared to LP, } \\
\text { except for leg curl. }\end{array}$ \\
\hline $\begin{array}{l}\text { Ullrich } \\
\text { et al. (2016) }\end{array}$ & $\begin{array}{l}\text { - } \mathrm{N}=11,5 \text { men \& } 6 \\
\text { women } \\
\text { - Judo } \\
\text { - } 4 \text { weeks, } 3 \text { x per week }\end{array}$ & $\begin{array}{l}\text { - } 1 \mathrm{RM} \text { bench press } \\
\text { - } 1 \mathrm{RM} \text { squat } \\
\text { - Isometric leg } \\
\text { extension } 70^{\circ} \\
\text { - Isometric leg } \\
\text { curl } 30^{\circ}\end{array}$ & $\begin{array}{l}\cdot \text { LP vs UP } \\
\cdot(\text { TP vs DUP) }\end{array}$ & $\begin{array}{l}\text { After a short period of time, both } \\
\text { models showed improvements in } \\
\text { maximum muscle strength both in legs } \\
\text { and arms. }\end{array}$ \\
\hline $\begin{array}{l}\text { Franchini } \\
\text { et al. (2015) }\end{array}$ & $\begin{array}{l}\text { - } \mathrm{N}=13 \text {, men } \\
\text { - Judo } \\
\text { - } 8 \text { weeks, } 5 \text { x per week }\end{array}$ & $\begin{array}{l}\text {-1RM bench press } \\
\text {-1RM squat }\end{array}$ & - LP vs UP & $\begin{array}{l}\text { Similar effects of improving the ability } \\
\text { were observed after the application of } \\
\text { both models. }\end{array}$ \\
\hline $\begin{array}{l}\text { Bartolomei } \\
\text { et al. (2014) }\end{array}$ & $\begin{array}{l}\text { - } \mathrm{N}=24 \text {, men } \\
\text { Throwing events, } \\
\text { Rugby, and American } \\
\text { football } \\
\text { - } 15 \text { weeks, } 4 \text { x per } \\
\text { week }\end{array}$ & $\begin{array}{l}\text {-1RM bench press } \\
\text { - Isometric half squat }\end{array}$ & - BP vs TP & $\begin{array}{l}\text { BP proved to be a better solution } \\
\text { for the development of the upper } \\
\text { extremities' strength, while there is no } \\
\text { difference in the lower. }\end{array}$ \\
\hline $\begin{array}{l}\text { Painter } \\
\text { et al. (2012) }\end{array}$ & $\begin{array}{l}\text { - } \mathrm{N}=26,19 \text { men } \& 7 \\
\text { women } \\
\text { - Track athletes } \\
\text { - } 10 \text { weeks, } 3 \text { x per } \\
\text { week }\end{array}$ & -1RM squat & $\begin{array}{l}\cdot \text { BP vs UP } \\
\bullet \text { (BP vs DUP) }\end{array}$ & $\begin{array}{l}\text { BP compared to UP showed a greater } \\
\text { impact on improving the maximum } \\
\text { strength. }\end{array}$ \\
\hline $\begin{array}{l}\text { Hoffman } \\
\text { et al. (2009) }\end{array}$ & $\begin{array}{l}\text { - } \mathrm{N}=51, \text { men } \\
\text { - American football } \\
\text { - } 15 \text { weeks, } 4 \text { x per } \\
\text { week }\end{array}$ & $\begin{array}{l}\text {-1RM bench press } \\
\text {-1RM squat }\end{array}$ & $\begin{array}{l}\cdot \mathrm{NP} \text { vs LP vs UP } \\
\cdot(\mathrm{NP} \text { vs PL/TPL vs NLP) }\end{array}$ & $\begin{array}{l}\text { With the application of all three } \\
\text { models, bench press and squat are } \\
\text { significantly improved. There is no } \\
\text { difference between the models. }\end{array}$ \\
\hline $\begin{array}{l}\text { Hoffman } \\
\text { et al. }(2003)\end{array}$ & $\begin{array}{l}\text { - } \mathrm{N}=28, \text { men } \\
\text { - Soccer } \\
\text { - } 12 \text { weeks, } 2 \text { x per } \\
\text { week }\end{array}$ & $\begin{array}{l}\text {-1RM bench press } \\
\text {-1RM squat }\end{array}$ & $\begin{array}{l}\cdot \text { NP vs UP } \\
\cdot(\text { LP vs NLP) }\end{array}$ & $\begin{array}{c}\text { During the season, significant progress } \\
\text { was observed with the application of } \\
\text { the NP only in squat. No observed } \\
\text { model has made significant progress in } \\
\text { bench press. }\end{array}$ \\
\hline $\begin{array}{l}\text { Kraemer } \\
\text { et al. }(2003)\end{array}$ & $\begin{array}{l}\text { - } \mathrm{N}=27 \text {, woman } \\
\text { - Tennis } \\
\text { - } 9 \text { months, } 3 \text { x per week }\end{array}$ & $\begin{array}{l}\text {-1RM bench press } \\
\text {-1RM leg press }\end{array}$ & $\begin{array}{l}\text { • UP vs NP } \\
\text { • (NLP vs NP vs Control) }\end{array}$ & $\begin{array}{l}\text { Using both models, after } 9 \text { months, } \\
\text { bench press and squat are significantly } \\
\text { improved. }\end{array}$ \\
\hline
\end{tabular}

Legend: BP - Block Periodization Model; TP - traditional periodization model; LP - linear periodization model; UP - Undulating periodization model; NP - non-periodized model; NLP - non-linear periodization in the original paper; PL / TPL - linear periodization / traditional linear periodization in the original paper; NLP - nonlinear periodization model in the original paper; Control - the control group in the original paper; DUP - daily undulating model of periodization in its original paper. 


\section{DISCUSSION}

Before discussing the reasons for theoretical reductions, as well as results of the study (after reductions), it is necessary to make certain observations relates the validity of the results of the analyzed research. There are a few:

1. Variation of the training load during the duration of the experiment protocol. Already in the first classification of non-periodized and periodized models of the training plan, the first theoretical and methodological dilemmas come to light. Namely, the question arises as to whether there were deload periods as a postulate and the essence of the very concept of periodization, i.e. whether is methodologically correct to distinguish the linear and the undulating periodization model (which are classified in periodized models for this research, although they are practically non-periodized) from the really non-periodized model (uniform and random variant), or it is correct to observe them as traditional and block model (which are periodized in the true sense of the word; by all criteria)?

2. Designs of analyzed studies do not declare the periodization model that was used by athletes prior to experimental factors. In this context, it could be assumed that the change in the training program itself will cause a different degree of biomotor, energy and coordination adaptations, and if it has been utilized for some time, it can be expected that continuation of exercise by the same model will have a reduced response (accommodation). Consequently, the conclusions go to the detriment of those models that are most often applied, i.e. if it is assumed that the traditional periodization model is the most utilized in sports practice, it is obvious that this model of periodized training will prove to be less efficient than it may be.

3. Unclearly defined factors which can influence the efficiency of the periodization model (declared or real). These are primarily specificity of the load and the total amount of work, but also the period of the season, as well as the career stages in which experimental exercise (factor) was applied. Also, the duration of the experimental factor is another of the administered criteria which, by its unprocessed duration, certainly influences the sensitivity of the process, and thus the very process of learning. Similar observations have been made by other authors, i.e. in conclusion, according to this analysis, it is important to point out that the results of the experiments were not analyzed and tested in relation to the hypotheses that were set, therefore the analyzes were mostly one-dimensional, and other methodological inconsistencies were noted too, above all, the integrality of the reaction of the subjects to the training stimuli (Afonso, Nikolaidis, Sousa, \& Mesquita, 2017). According to Afonso at al., the concepts of periodization are also debatable, but also the authors need to use variation of load variables as a synonym for periodization. In such a context of experimental design an essential methodological problem arises, and it is that the declared periodization models are not periodization models, because under the periodization of biomotor abilities it implies that "the goals, contents, and methods of strength training programs change during the phase of the training plan, which is most often tied to the training year" (Bompa, 2009). Practically, for the shorter periods of the training cycle, the term "periodization" should not be used, but the use of the term "training adaptation in relation to the method and content of training" might be more appropriate here. In the mentioned context, even more obvious inadequate use of the term "periodization" is if we observe periodization in a broader context - as a strategy for training activities that leads to overall transformation and an integral optimization of all the athlete's potentials for the performance at the specific competition.

4. Application of a constant amount of training load in the linear (change in volume followed by change in intensity) and non-periodized (uniform variant) training model (constant values of volume and intensity). Bearing in mind that the authors emphasize (Kraemer et al., 2003; Hoffman et al., 2009) that the load in non-periodized model was tailored at every training session, i.e. it is suggested that the last anticipated repetition be performed with the same maximum effort, it is obvious that the load in the absolute values was increasing during the application of experimental factor. Consequently, it still has some changes from the internal aspect of adaptation, and in some sense, it is not completely uniform. Accordingly, in certain specific situations it has an internal structure similar to the linear model (the volume of repetition to "failure", with the subjective feeling of the subject). Bearing this in mind, but also that neither linear nor uniform model have deload periods, it would be reasonable to consider them as variants of a non-periodized model. 


\section{Examples of design and theoretical starting point - the reasons for reduction}

In the research of Manchado et al. (2018), a traditional and a block periodization model were compared, where the handball players of one season were trained according to the traditional model during the preparatory period, while in the following season they trained according to the block model during the preparatory period. With both models, the entire training program with the intent of developing strength (but also with the intent of developing endurance) was applied through 3 phases (mesocycles - MSC) for the traditional model: general preparation (GP), specific preparation (SP) and competition (C); i.e. for block model through phases: accumulation $(\mathrm{A})$, transformation $(\mathrm{T})$ and realization $(\mathrm{R})$. The first phases in both models (GP \& A) involve work on strength development. During 4 weeks of the traditional model, program consisted of work in 3 sets of 10 repetitions at $60 \%$ of $1 \mathrm{RM}$ (in $1^{\text {st }}$ week), 3 sets of 10 reps at $65 \%$ of $1 \mathrm{RM}$ ( $2^{\text {nd }}$ week $), 3$ sets of 9 reps at $70 \%$ of $1 \mathrm{RM}$ ( $3^{\text {rd }}$ week), and 3 sets of 8 reps at $75 \%$ of $1 \mathrm{RM}$ ( $4^{\text {th }}$ week), while for the block model for all 5 weeks (one week longer!) program involved a smaller repetition rate - from 1 to 4 - but with intensity between $80 \%$ and $95 \%$ of 1 RM. During the second phase, in both observed models (SP \& T), the focus was on power developing. In the traditional model, the program consisted of work with 5 to 6 reps at $75 \%$ to $85 \%$ of $1 \mathrm{RM}$ during the first three weeks, and during the last week, $50 \%$ to $60 \%$ of $1 \mathrm{RM}$ (deload). On the other hand, the block model involved in all 5 weeks (again one week longer!) performing exercises with maximum velocity at $75 \%$ to $80 \%$ of $1 \mathrm{RM}$. The third phase (C \& R) involved the development of the specific strength required for handball, during 8 weeks at the traditional, and 6 weeks (two weeks shorter!) at the block model. Bearing in mind that there are certain changes in total amount of load, it can be considered that the shown models are named with appropriate names. On the other hand, although both models last the same, the problem is in the unequal duration of the phases during which a certain experimental factor was operating. Even the authors themselves state that during the first phase, both training programs were carried out using the same exercises in the same weekly training session and that the difference was only in the intensity and volume.

In the research of Ullrich et al. (2018), the traditional model involved increasing intensity every 2 weeks $-1^{\text {st }}$ and $2^{\text {nd }}$ week 6 sets of 7 jumps with $0 \%$ of body weight ( $1^{\text {st }}$ type of workout); $3^{\text {rd }}$ and $4^{\text {th }}$ week 6 sets of 5 jumps with $15 \%$ of body weight $\left(2^{\text {nd }}\right.$ type of workout); $5^{\text {th }}$ and $6^{\text {th }}$ week 6 sets of 3 jumps with $30 \%$ of body weight ( $3^{\text {rd }}$ type of workout) - which is a characteristic of the linear model because there is no deload period, and the volume decreases and the intensity increase. For this reason, for the purposes of this paper, it was observed as a linear model. On the other hand, the daily undulating model involved different order of training sessions with different workloads $\left(1^{\text {st }}, 2^{\text {nd }}\right.$, and $3^{\text {rd }}$, type of the workout), so it was observed as an undulating model.

In the research of Tammam \& Hashem (2016), the names of the periodization models are in line with the terminology used in this paper. Namely, for the linear (progressive) model, the exercise program from $1^{\text {st }}$ to $3^{\text {rd }}$ week consisted of work in 3 sets of 10RM (10-repetition maximum), from $4^{\text {th }}$ to $6^{\text {th }}$ week 3 sets of $8 \mathrm{RM}$, from $7^{\text {th }}$ to $9^{\text {th }}$ week 3 sets of $6 \mathrm{RM}$, and from $10^{\text {th }}$ to $12^{\text {th }}$ week 3 sets of $4 \mathrm{RM}$. In the biweekly non-linear model (in original paper), training program involved work in $1^{\text {st }}$ and $2^{\text {nd }}$ week in 3 sets of $10 \mathrm{RM}$, in $3^{\text {rd }}$ and $4^{\text {th }}$ week in 3 sets of $8 \mathrm{RM}, 5^{\text {th }}$ and $6^{\text {th }}$ week 3 sets of $4 \mathrm{RM}$, in $7^{\text {th }}$ and $8^{\text {th }}$ week 3 sets of $10 \mathrm{RM}$, in $9^{\text {th }}$ and $10^{\text {th }}$ week 3 sets of $6 \mathrm{RM}$, and in $11^{\text {th }}$ and $12^{\text {th }}$ week 3 sets of $4 \mathrm{RM}$, which characterizes the properly mentioned periodization model, so in this paper it was observed as an variant of undulating model.

In another research by Ullrich et al. (2016), inconsistency in the model names was observed. Namely, the traditional model involved a way of exercising where after 4 training sessions the intensity of exercise was decreasing. Specifically for squat, in the first 4 training sessions (T1, T2, T3, T4), the exercise program involved work in 3 sets of 1 to 2 repetitions from $80 \%$ to $90 \%$ of $1 \mathrm{RM}$ (strength zone); from T5 to T8 in 3 sets of 1 to 4 reps from $65 \%$ to $75 \%$ of $1 \mathrm{RM}$ (power zone); from T9 to T12 in 3 sets of 3 to 6 reps from $50 \%$ to $60 \%$ of $1 \mathrm{RM}$ (speed zone). For bench press and leg curl exercises the program was similar just with a different number of repetitions at the same intensities of 1RM (and zones). At first glance, it can be seen that it is the linear (reverse) model rather than a traditional one as stated. Although for all exercises (and even for the three selected in this paper), a slight deload was observed in certain training sessions in the form of a reduction of one repetition compared to previous training session (for squat at $\mathrm{T} 4, \mathrm{~T} 8$, and $\mathrm{T} 12$, 1 repetition), and this type of work seemingly could be defined as a traditional model, but this has not been done because the deload is such that it is carried out within the same microcycle (MC), i.e. 
there is no deload period (there is only one training session with reduced load, not the entire MC).

In the research of Franchini et al. (2015), the linear (reverse) model was compared with the undulating model. In the liner model, the training program during the first 2 weeks involved work in 4 sets of 3 to 5 reps ( $1^{\text {st }}$ type of workout), during the next 3 weeks in 4 sets of 6 to 8 reps at $80 \%$ of 1 RM ( $2^{\text {nd }}$ type of workout), and 15 to 20 reps during the last 3 weeks ( $3^{\text {rd }}$ type of workout). In the undulating model, the training program also involved 3 training sessions per week, with each one of them being one of the three different types of workouts. In the coming weeks, only their order within the week is changed, except in the $5^{\text {th }}$ and $7^{\text {th }}$ week. During those weeks, workout with 3 to 5 reps, was replaced by the workout with 6 to 8 reps at $80 \%$ from 1 RM (Monday and Friday in $5^{\text {th }}$ week) and with 15 to 20 reps (Monday and Friday in $7^{\text {th }}$ week). The authors used terminology in both models in accordance with the terminology used in this paper.

In the research of Bartolomei et al. (2014), the traditional model and the block model were compared. In the traditional model, the exercise program consisted of 3 MSC lasting 5 weeks (apparently authors - not only in the above-mentioned work - instead of the term microcycle, use the term "week"!) with 2 training sessions per week for which the experimental factor was applied (the program involved 4 training sessions per week for strength development, but there were only 2 exercises for those observed in this paper). In all 3 MSC the order of the weeks was the same - $1^{\text {st }}$ week 5 sets of 8 to 10 reps from $65 \%$ to $75 \%$ of $1 \mathrm{RM} ; 2^{\text {nd }}$ week 5 sets of 5 to 6 reps from $75 \%$ to $85 \%$ of $1 \mathrm{RM}$; $3^{\text {rd }}$ week 5 sets of 3 to 4 reps from $85 \%$ to $95 \%$ of $1 \mathrm{RM}$; $4^{\text {th }}$ week from $50 \%$ to $60 \%$ of $1 \mathrm{RM} ; 5^{\text {th }}$ week work with small load magnitude and through only 2 training sessions (deload). Practically, the program implied repeating a linear progressive model with last deload week, where the absolute load magnitudes (in $\mathrm{kg}$ ) were tailored to meet the individual needs of the subject (increasing the absolute load magnitude to keep the intensity remaining in the predicted range). With the block model, the training program involved the same number of MSC as in the traditional model, as well as weeks and training sessions. The training program in the $1^{\text {st }}$ MSC involved work on muscular hypertrophy (accumulation) with an intensity from $65 \%$ to $75 \%$ of $1 \mathrm{RM}$ through 6 to 10 reps, then work on strength (transformation) during $2^{\text {nd }}$ MSC, with an intensity from $80 \%$ to $95 \%$ of 1 RM through 1 to 6 reps, and finally the $3^{\text {rd }}$ MSC training program involved work on the power (realization), with an intensity from $50 \%$ to $65 \%$ of $1 \mathrm{RM}$ through the maximum speed of performing. Bearing in mind that in the block model at the end of each MSC, a deload week is predicted, it is obvious that both models can be classified as named by the authors - the traditional model and the block model.

In the research of Painter et al. (2012), the block model and the (daily) undulating periodization model were compared. In the block model, through 3 blocks (for developing endurance, strength and power) volume and intensity were manipulated both within a week and during weeks, while in the (daily) undulating model change was performed only within a week ( $1^{\text {st }}$ training session 3 sets of 8 to 12 reps; $2^{\text {nd }}$ training session 3 sets of 5 to 7 reps; $3^{\text {rd }}$ training session 3 sets of 3 to 5 reps) where the same contents of the week are repeated over the entire period. If the weeks are analyzed (like MC) it can be noticed that in the first 4 weeks, the initial weekly load increases, while in the last one decrease. Next, the same pattern was repeated in the next 4 weeks. Although in the tables of the original paper is stated that it is the traditional model, it is obvious that the term "traditional" was used with the meaning "common", and for this reason, it was also observed in this paper as a block model.

In the research of Hoffman et al. (2009), the names of the periodization models are not fully in line with the terminology used in this paper. During 4 training sessions per week for developing strength, bench press and squat were performed on 2 training sessions alternately. In the non-periodized model, training plan consisted of 4 sets ( 5 sets in the last 4 weeks) of 6 to 8 reps throughout the entire period. This name corresponds to the terminology used in this paper. In the traditional periodized linear model (as the authors call it) during the first 4 weeks the exercising involved 4 sets of 9 to 12 reps, over the next 6 weeks in 4 sets of 6 to 8 reps, and during the last 4 weeks in 5 sets of 3 to 5 reps. Obviously, this is a linear model, not the traditional one. Also, in the non-linear model during the first 4 weeks, the work involved 4 sets of 3 to 5 reps at the first and 9 to 12 reps at the second training session of the week (for the squat inversely). During the next 6 weeks work involved the same 4 sets of 3 to 5 reps at the first and 9 to 12 repetitions in the second training session of the week (for the squat inversely), but with a different order of other exercises. During the last 4 weeks work involved 5 sets of 3 to 5 reps at the first and 9 to 12 reps at the second training session of the week (for the squat inversely). All these characterize the properly mentioned periodization 
model, so in this paper it was observed as an variant of undulating model.

In another research by Hoffman et al. (2003), the names of the periodization models are inconsistent with the terminology used in this paper. Namely, 4 exercises - power clean, squat, push press, bench press - were applied 2 times per week for 12 weeks. The linear model involved exercising during the week on two identical training sessions, with $80 \%$ of the $1 \mathrm{RM}$ and in a volume of 3 sets of 3 to 5 reps for power clean, 6 to 8 reps for squat, 4 to 6 reps for push press, and 6 to 8 reps for bench press. This name does not correspond to the terminology used in this paper, because the same program is involved throughout all 12 weeks. For this reason, this is a uniform non-linear model rather than a linear one, since it is obvious that - observed for each exercise separately - there is no variation of the external load variables. In the nonlinear model, the same exercises were applied twice a week, but with different load magnitudes. Once a week with an intensity of $70 \%$ of $1 \mathrm{RM}$ and in a volume of 3 sets of 4 to 6 reps for power clean, from 8 to 10 reps for squat, from 4 to 6 reps for push press, and from 8 to 10 reps for bench press. The second training session in the week was conducted according to a program that involved a $90 \%$ intensity of $1 \mathrm{RM}$ with a volume of 3 sets of 2 to 4 reps for all exercises. All these characterize the properly mentioned periodization model, so in this paper it was observed as an variant of undulating model.

In the research of Kremer et al. (2003), in the nonperiodized model, it was exercised with such load magnitudes throughout the entire period that it was possible to perform 8 to 10 reps in 3 sets, while in the non-linear model the intensity was changed at each training session within a week (Mondays 3 sets of 4 to 6 reps; Tuesdays 3 sets of 8 to 10 reps, and Fridays 3 sets of 12 to 15 reps). For this reason, in this paper, a non-linear model is observed as a (daily) undulating model. At this point, it is important to note that the load magnitude in both models was defined by the external characteristics, but they increased in absolute values during the period of the experimental factor.

If we look at the publishing time of the analyzed studies in which the name of the applied periodization model has been changed (due to discrepancies with the attached training programs), it can be concluded that in recent years, the authors have somehow recognized the problems pointed out in this paper, so the need for correction of terminological inconsistencies was reduced. However, in order to completely discredit the discourse of the results and conclusions of the researches, whose subject is to monitor the effects of the periodized work, it is necessary to precisely define the theoretical as well as the methodological framework of the research that will be objective, purposeful and reliable.

Besides the necessity of respecting the observations mentioned at the beginning of the chapter Discussion (second and third observation), one of the first steps towards a clearer definition of the mentioned frameworks, surely could be a simplification of the model classification according to the basic criterion - the existence or absence of the deload period, i.e. the variability of the training load (first observation). Namely, although the different variants of the programmed exercise involve relatively similar variations of the load variables (primarily volume and intensity), they in their essence differ by whether the total load over time changes or does not change. In this context, although they contain segments that can be identical to the linear or the undulating model (as well as the uniform model), the traditional and the block model are classified as periodized models. On the other hand, the linear and the undulating model are characterized by a constant inverse interdependence of the load variables, by which they maintain a relatively similar load volume throughout the entire duration of the programmed exercise. In this context, it is possible to make a large number of variations (linear, reversed linear, undulating on a daily or weekly level, etc.) or even omit them (uniform model), but the essence will remain the same - the load variables are never reduced simultaneously, thus the reduction of one, is followed by the increase of another. As a result, the load is adding up to the load, which is possible only in relatively short periods of time. Bearing in mind that periodization as a concept - among other things - involves longer periods of time, as well as varying of the total training load during those periods, it is obvious that the mentioned models differ essentially from one another.

The justification for this attempt to classify the models - into periodized and non-periodized - in addition to the above mentioned theoretical explanation, to some extent, could also include the results of this study. Namely, the block model is the only model that, no research has shown to be a worse solution for improving the observed abilities than some other models. Only where it didn't produce better effects but equal - is in comparison to the traditional model, specifically for leg muscles. On the other hand, by observing other models (linear, undulating, non-pe- 
riodized) it is obvious that all these types of work improve abilities, but it is not possible to determine with certainty which is the optimal solution (perhaps because there is no difference between them). Finally, in a single study, the block model was compared with the undulating model (periodized with non-periodized), where the block proved to be a better solution. In this last statement lie the reason and the justification for classifying only on two classes of the model - periodized and non-periodized. Also, the traditional model was not compared to any other model, other than the block model (only in two studies), therefore this is also a fact that needs to be kept in mind. In any case, this issue is also in need of further research primarily comparing the influence of the traditional with the other models - but certainly with a different theoretical starting point from the one found so far in the works that dealt with this topic.

\section{CONCLUSION}

Block periodization model is potentially the best solution for developing the strength of athletes. This conclusion was imposed after a multilateral analysis of a large number of published papers in categorized scientific journals, whose subject and problem can be related to the key words of this paper (periodization / muscular strength / cognitive paradigm / methodological reduction / scientific periodic). When it comes to the strength of the legs, an equally good solution is the application of the traditional periodization model. On the other hand, the block model proved to be significantly better than the undulating model, which opens the possibility that, indirectly, other affirmative conclusions can be drawn about the significance of this model (as well as the periodized models in general) on the development of observed motor abilities of athletes. Also, the use of other models (non-periodized in its essential form, in which there are no variations of the total load in the observed period) improves the strength of athletes, but it is not possible to determine which model of periodized work is an optimal solution.

On the other hand, after theoretical, purpose and meaning analysis, as well as applied methodological framework, it is obvious that the scientific journals and publications need to clearly define the periodization model/models that will be used, or in other words they need to provide an answer to this question before the setting of the experimental protocol.

First of all, the concepts of periodization and using variation (in short term) of load variables as a synonym for periodization are debatable. Further, there are the criteria for classifying the model in terms of the existence or absence of a deload period (change in the total amount of load). The validity of the conclusions can certainly be influenced by the periodization models used by athletes before being exposed to experimental factors; in this case the potentially favored models are the ones that have not been applied so far, because the continuation of the work by the same periodization model may have a reduced response (accommodation). Other factors may also influence the effectiveness of the periodization model, therefore they need to be defined more clearly - specificity of the load, the amount of work, the period of the season or stage of the athlete's career, the integrality of the reaction to the total training stimuli and the duration of the experimental factor.

Editors of scientific journals and editors of sections, as well as reviewers, must pay attention to the theoretical frameworks of studies in order to produce a methodological framework of research that will be objective, purposeful, reliable... On the path of knowledge and conclusions about the adaptation process of organic systems in response to the specificity of the research protocol design, it is necessary for the authors to set up a protocol that is sensitive to the problem and the goal of the research. In other words, it must be without theoretical reductions leading to methodological inconsistencies and to low applicability in practical work in programmed physical activity and sports.

\section{REFERENCES}

1. Afonso, J., Nikolaidis, P. T., Sousa, P., \& Mesquita, I. (2017). Is Empirical Research on Periodization Trustworthy? A Comprehensive Review of Conceptual and Methodological Issues. Journal of Sports Science and Medicine, 16(1), 27-34.
2. Baechle, T. R., \& Earle, R. W. (2008). Essentials of strength training and conditioning, 3rd edition. Human kinetics. 
3. Baker, D., Wilson, G., \& Carlyon, R. (1994). Periodization: The effect on strength of manipulating volume and intensity. The Journal of Strength and Conditioning Research, 8(4), 235-42.

4. Bartolomei, S., Hoffman, J. R., Merni, F., \& Stout, J. R. (2014). A comparison of traditional and block periodized strength training programs in trained athletes. The Journal of Strength and Conditioning Research, 28(4), 990-997.

5. Bompa, T. O. (2009). Periodizacija: teorija i metodologija treninga. [Periodization: training theory and methodology. In Croatian]. Zagreb: Gopal.

6. Bompa, T. O., \& Buzzichelli, C. (2018). Periodization: Theory and Methodology of Training. Human Kinetics.

7. Bompa, T. O., \& Haff, G. G. (2009). Periodization: Theory and Methodology of Training, 5th edition. Human Kinetics.

8. Buford, T. W., Rossi, S. J., Smith, D. B., \& Warren, A. J. (2007). A comparison of periodization models during nine weeks with equated volume and intensity for strength. The Journal of Strength and Conditioning Research, 21(4), 1245-1250.

9. Caldas, L. C., Guimarães-Ferreira, L., Duncan, M. J., Leopoldo, A. S., Leopoldo, A. P. L., \& Lunz, W. (2016). Traditional vs. undulating periodization in the context of muscular strength and hypertrophy: a meta-analysis. International Journal of Sports Science, 6, 219-229.

10. Clemente-Suárez, V. J., Fernandes, R. J., ArroyoToledo, J. J., Figueiredo, P., González-Ravé, J. M., \& Vilas-Boas, J. P. (2015). Autonomic adaptation after traditional and reverse swimming training periodizations. Acta Physiologica Hungarica, 102(1), 105-113.

11. DeWeese, B. H., Gray, H. S., Sams, M. L., Scruggs, S. K., \& Serrano, A. J. (2013). Revising the definition of periodization: merging historical principles with modern concern. Olympic Coach, 24(1), 5-19.

12. Fleck, S. J. (1999). Periodized strength training: a critical review. The Journal of Strength and Conditioning Research, 13(1), 82-89.

13. Franchini, E., Branco, B. M., Agostinho, M. F., Calmet, M., \& Candau, R. (2015). Influence of linear and undulating strength periodization on physical fitness, physiological, and performance responses to simulated judo matches. The Journal of Strength and Conditioning Research, 29(2), 358-367.
14. Grgic, J., Mikulic, P., Podnar, H., \& Pedisic, Z. (2017). Effects of linear and daily undulating periodized resistance training programs on measures of muscle hypertrophy: a systematic review and meta-analysis. PeerJ, 5, e3695.

15. Grgic, J., Lazinica, B., Mikulic, P., \& Schoenfeld, B. J. (2018). Should resistance training programs aimed at muscular hypertrophy be periodized? A systematic review of periodized versus nonperiodized approaches. Science \& Sports, 33(3), 97-104.

16. Haff, G. G., \& Triplett, N. T. (2015). Essentials of Strength Training and Conditioning 4th edition. Human Kinetics.

17. Harries, S. K., Lubans, D. R., \& Callister, R. (2015). Systematic review and meta-analysis of linear and undulating periodized resistance training programs on muscular strength. The Journal of Strength and Conditioning Research, 29(4), 1113-1125.

18. Herrick, A. B., \& Stone, W. J. (1996). The effects of periodization versus progressive resistance exercise on upper and lower body strength in women. The Journal of Strength and Conditioning Research, 10(2), 72-76.

19. Hoffman, J. R., Ratamess, N. A., Klatt, M., Faigenbaum, A. D., Ross, R. E., Tranchina, N. M., ... \& Kraemer, W. J. (2009). Comparison between different off-season resistance training programs in Division III American college football players. The Journal of Strength and Conditioning Research, 23(1), 11-19.

20. Hoffman, J. R., Wendell, M., Cooper, J., \& Kang, J. (2003). Comparison between linear and nonlinear in-season training programs in freshman football players. Journal of Strength and Conditioning Research, 17(3), 561-565.

21. Issurin, V. (2009). Blok periodizacija: Prekretnica $u$ sportskom treningu. [Block periodization: The turning point in sports training. In Serbian]. Beograd: Data Status.

22. Junior, A. C. T., \& Drigo, A. J. (2017). Application of training periodization models by elite judo coaches. Archives of Budo, 13(1), 139-146.

23. Kraemer, W. J., \& Ratamess, N. A. (2004). Fundamentals of resistance training: progression and exercise prescription. Medicine and Science in Sports and Exercise, 36(4), 674-688. 
24. Kraemer, W. J., Häkkinen, K., Triplett-McBride, N. T., Fry, A. C., Koziris, L. P., Ratamess, N. A., ... \& Gordon, S. E. (2003). Physiological changes with periodized resistance training in women tennis players. Medicine \& Science in Sports \& Exercise, 35(1), 157-168.

25. Kramer, J. B., Stone, M. H., O’bryant, H. S., Conley, M. S., Johnson, R. L., Nieman, D. C., ... \& Hoke, T. P. (1997). Effects of single vs. multiple sets of weight training: impact of volume, intensity, and variation. Journal of Strength and Conditioning Research, 11, 143-147.

26. Manchado, C., Cortell-Tormo, J. M., \& TortosaMartínez, J. (2018). Effects of Two Different Training Periodization Models on Physical and Physiological Aspects of Elite Female Team Handball Players. The Journal of Strength and Conditioning Research, 32(1), 280-287.

27. Mattocks, K. T., Dankel, S. J., Buckner, S. L., Jessee, M. B., Counts, B. R., Mouser, J. G., ... \& Loenneke, J. P. (2016). Periodization: what is it good for? Journal of Trainology, 5(1), 6-12.

28. Miranda, F., Simão, R., Rhea, M., Bunker, D., Prestes, J., Leite, R. D., ...\& Novaes, J. (2011). Effects of linear vs. daily undulatory periodized resistance training on maximal and submaximal strength gains. The Journal of Strength and Conditioning research, 25(7), 1824-1830.

29. Monteiro, A. G., Aoki, M. S., Evangelista, A. L., Alveno, D. A., Monteiro, G. A., da Cruz Piçarro, I., \&Ugrinowitsch, C. (2009). Nonlinear periodization maximizes strength gains in split resistance training routines. The Journal of Strength and Conditioning Research, 23(4), 1321-1326.

30. Moraes, E., Fleck, S. J., Dias, M. R., \& Simão, R. (2013). Effects on strength, power, and flexibility in adolescents of nonperiodized vs. daily nonlinear periodized weight training. The Journal of Strength \& Conditioning Research, 27(12), 33103321.

31. Nunes, J. P., Ribeiro, A. S., Schoenfeld, B. J., \&Cyrino, E. S. (2018). Comment on: "Comparison of Periodized and Non-Periodized Resistance Training on Maximal Strength: A Meta-Analysis". Sports Medicine, 48(2), 491-494.

32. O’bryant, H. S., Byrd, R., \& Stone, M. H. (1988). Cycle ergometer performance and maximum leg and hip strength adaptations to two different methods of weight-training. The Journal of Strength and Conditioning Research, 2(2), 27-30.
33. Painter, K. B., Haff, G. G., Ramsey, M. W., McBride, J., Triplett, T., Sands, W. A., ... \& Stone, M. H. (2012). Strength gains: Block versus daily undulating periodization weight training among track and field athletes. International Journal of Sports Physiology and Performance, 7(2), 161-169.

34. Rhea, M. R., \& Alderman, B. L. (2004). A meta-analysis of periodized versus nonperiodized strength and power training programs. Research quarterly for exercise and sport, 75(4), 413-422.

35. da Silva, F. P., Vilaça-Alves, J., de Souza, L. L., dos Santos, J. S., \&Figueiredo, T. (2016). Effects of Daily and Flexible Non-Linear Periodization on Maximal and Submaximal Strength, Vertical Jump and Speed Performance of Brazilian Army Skydivers. International Journal of Sports and Exercise Medicine, 2, 047.

36. Souza, E. O., Ugrinowitsch, C., Tricoli, V., Roschel, H., Lowery, R. P., Aihara, A. Y., ... \& Wilson, J. M. (2014). Early adaptations to six weeks of non-periodized and periodized strength training regimens in recreational males. Journal of Sports Science and Medicine, 13(3), 604-609.

37. Stone, M. H., Potteiger, J. A., Pierce, K. C., Proulx, C. M., O’bryant, H. S., Johnson, R. L., \& Stone, M. E. (2000). Comparison of the effects of three different weight-training programs on the one repetition maximum squat. The Journal of Strength and Conditioning Research, 14(3), 332-337.

38. Storer, T. W., Dolezal, B. A., Berenc, M. N., Timmins, J. E., \& Cooper, C. B. (2014). Effect of supervised, periodized exercise training vs. selfdirected training on lean body mass and other fitness variables in health club members. The Journal of Strength and Conditioning Research, 28(7), 1995-2006.

39. Strohacker, K., Fazzino, D., Breslin, W. L., \&Xu, X. (2015). The use of periodization in exercise prescriptions for inactive adults: A systematic review. Preventive Medicine Reports, 2, 385-396.

40. Tammam, A. H., \&Hashem, E. M. (2016). The Effect of Linear and Biweekly Non-Linear Periodized Resistance Training on Maximal Strength and Vertical Jump for Volleyball Players.Journal of Applied Sports Science, 6(1), 73-81.

41. Ullrich, B., Pelzer, T., \& Pfeiffer, M. (2018). Neuromuscular Effects to 6 Weeks of Loaded Countermovement Jumping With Traditional and Daily Undulating Periodization. The Journal of Strength and Conditioning Research, 32(3), 660-674. 
42. Ullrich, B., Pelzer, T., Oliveira, S., \& Pfeiffer, M. (2016). Neuromuscular responses to short-term resistance training with traditional and daily undulating periodization in adolescent elite judoka. The Journal of Strength and Conditioning Research, 30(8), 2083-2099.
43. Williams, T. D., Tolusso, D. V., Fedewa, M. V., \&Esco, M. R. (2017). Comparison of periodized and non-periodized resistance training on maximal strength: a meta-analysis. Sports Medicine, 47(10), 2083-2100.

Submitted: 05.05.2019.

Accepted: 07.06. 2019.

Published Online First: 01.07.2019. 


\title{
МОДЕЛИ ПЕРИОДИЗАЦИЈЕ У ИСТРАЖИВАЊИМА ЈАЧИНЕ МИШИЋА КОД СПОРТИСТА, ТЕОРИЈСКО-МЕТОДОЛОШКЕ РЕДУКЦИЈЕ ИЛИ НЕКРИТИЧКИ ПОЗИТИВИЗАМ У СПОРТСКО-НАУЧНОЈ ПЕРИОДИЦИ
}

\author{
Марко Ћосић \\ Факултет спорта и физичког васпитања, Универзитет у Београду, Србија
}

\begin{abstract}
Сажетак
Периодизација је теоријски и практични конструкт спортског тренинга који се односи на програмирање тренажних активности у међусобно зависним временским периодима, како би се изазвале специфичне физиолошке адаптације. У тренажном и такмичарском процесу користи се у функцији постизања резултата на циљаном такмичењу. Теоријско и практично утемељење процеса периодизације се између осталог може проучавати и са аспекта њеног утицаја на биомоторичке способности. У том контексту, опште место изучавања периодизације су истраживања која се тичу утицаја различитих модела периодизације на јачину мишића (предмет овог рада). На основу анализе садржаја, смисла, методолошке оријентације и закључивања унутар одабраног броја публикованих истраживања (метод сазнања), не може се са сигурношћу тврдити да ли периодизовани модели тренинга у простору мишићне јачине дају боље резултате од непериодизованог модела, као ни то, који модел од периодизованих модела у том смислу даје боље резултате. Наведене дилеме из предмета овог рада су потврђене и у неколико прегледних радова и мета-анализа. Ипак, прегледом методолошког и теоријског контекста тих студија, уочава се већи број дилема, пре свега она која се односи на узорак испитаника. Наиме, ни једна од анализираних студија у свом фокусу није имала само спортисте као циљну групу, већ су резултати истраживања спроведених над спортистима анализирани у односу на групу рекреативних вежбача или у односу на нетрениране испитанике. Такође, уочава се недоследност у терминологији примењиваних модела периодизације, чиме се отвара питање постојања јасног теоријског концепта и методичко-организационог конструкта којим се планира постизање такмичарског резултата. Претпоставка је да би се јасном анализом изворног контекста феномена периодизације, усклађивањем методичких и методолошких корака у процесу сазнања, јасном дистинкцијом према постојећим дефиницијама и терминологији, дошло и до оптимизације процеса сазнања које ће довести до препознавања модела периодизације који ће водити до оптималних циљева тренажно-такмичарске припреме. Дакле, проблем овог истраживања је проистекао из теоријске и методолошке неконзистентности истраживача у простору утицај различитих модела периодизације на јачину спортиста. Циљ рада је да се анализом и утврђивањем чињеница методолошког и теоријског конструкта периодизације разумеју закључци различитих истраживања, за које се може рећи да - и поред публиковања у значајним међународним часописима - воде до конфузије у простору закључивања о утицају различитих модела периодизације на јачину код спортиста. Након прегледа више од 80 радова публикованих у референтним часописима, селекцијом у односу на теоријско-методолошки и контекст дедуктивног закључивања, овом анализом је издвојено 10 истраживања у којима је упоређен утицај примене различитих модела периодизације на јачину код спортиста испољену при вежбама рукама и ногама. Резултати упућују да су примењени периодизовани модели, пре свега блок, показали виши степен сензитивности на развој јачине код спортиста, али је отворено и неколико важних питања која се тичу управо ваљаности закључивања о овој теми. Како год, исход и сврсисходност овог истраживања, треба сагледати као јасније дефинисање феномена периодизације и њених модела, као и препознати деловања експерименталног фактора у функцији биомоторичког одговора испитаника на тренажне стимулусе.
\end{abstract}

КљУчНе речИ: ПЕРИОДИЗАЦИЈА / МИШИЋНА ЈАЧИНА / САЗНАЈНА ПАРАДИГМА / МЕТОДОЛОШКА РЕДУКЦИЈА / НАУЧНА ПЕРИОДИКА 


\section{УВОД}

Периодизација је теоријски и практични конструкт који је заснован на логичном, методолошком, методичном и систематичном процесу планирања тренажних активности у јединствену целину која води до биомоторичких и психичких бенефита, како би се постигао врхунац тренажнотакмичарске форме у одговарајућим временским интервалима. Другим речима, то је програмирање тренажних активности у међусобно зависним временским периодима како би се изазвале специфичне физиолошке адаптације у функцији постизања резултата (Haff \& Triplett, 2015). У најширем контексту, за циљ има свеукупну трансформацију атрибута перформанси, односно, интегрално оптимизовање свих потенцијала спортисте за наступ на циљаном такмичењу. Поред тога што се периодизацијом стварају предуслови којима се обезбеђује да се спортска форма постигне на главном такмичењу, она се у методолошком и сазнајном контексту може и мора изучавати и са позиције свеукупних утицаја на биомоторичке способности (брзину, јачину, снагу, агилност и издржљивост) (Bompa \& Haff, 2009). Дакле, у ужем смислу, периодизација се односи и на структурирање фаза тренинга да би се третиране психомоторичке способности довеле на жељени ниво, сходно чему ће се у том контексту у овом раду и третирати.

\section{Периодизација - изазови и недоумице истраживачких протокола}

Спортска пракса и само вежбање су до данас изнедрили велики број варијанти организације тренажног процеса који су прерасли у моделе - теоријске и практичне конструкте - који се, у односу на предмет овог рада, могу поделити на непериодизоване и периодизоване. Проблематика незавршене тренажно-такмичарске праксе се усложњава коришћењем различите терминологије (семантичка недореченост) која се - нажалост - више примећује у научним часописима у односу на рад у непосредној пракси. Другим речима, истраживачки процеси се реализују на основу недовољно јасно дефинисаних критеријума за класификацију процеса који прате периодизацију. Након анализе публикованих ра- дова остаје нејасно да ли је процес периодизације суштински или формални критеријум биомоторичких адаптација, односно да ли су процес суперкомпензације и поставка растерећујућих периода тренинга кроз промене појединих компоненти тренажног оптерећења једини ефекти којима се обезбеђује интеграција кумулативних тренажних ефеката у изградњи такмичарског резултата?

У процесу научног сазнања феномена периодизованог тренинга и његових ефеката, користи се непериодизовани модел (Non-Periodized - NP) експерименталног фактора. Методолошке поставке оваквог експерименталног фактора (вежбања) су постављене у односу на равномерну (Uniform), линеарану (Linear) и насумичну (Random) варијанту периодизације (Strohacker, Fazzino, Breslin, \& Xu, 2015). Међутим, у целовитом и целисходном истраживачком дизајну, у ову групу експерименталног вежбања би требало сврстати само насумичну и равномерну варијанту, које подразумевају праћење несистематских промена у њиховом обиму и/или интензитету, односно константне вредности обима и интензитета током периода тренирања. У односу на мишићну јачину, ово би било потребно исказати бројем понављања и процентом од једног максималног понављања (1-repetition maximum; 1RM). Сврсисходност оваквог приступа у експерименталном дизајну треба тражити у одсуству било каквих биомоторичких циклуса у процесу тренажних адаптација, те се сходно томе не може ни говорити о периодизацији у њеном изворном теоријскопрактичном значењу.

Имајући у виду да периодизација подразумева варирање оптерећења у циљу олакшања интеграције планираних вежбања и замора изазваног тренингом, а у смислу прогресивног тока адаптација (DeWeese, Gray, Sams, Scruggs, \& Serrano, 2013), у том контексту би - у експерименталном дизајну - и линеарно тренажно оптерећење требало сврстати у непериодизовани модел, јер се под варирањем оптерећења не подразумева само промена вредности појединих компоненти оптерећења (где се једна повећава, а друга смањује), већ пре свега, варирање укупне количине оптерећења која води до кумулативних тренажно-такмичарских ефеката. Истина је да линеарне варијанте (прогресивна и обрнута) прате промене обима и интензитета током тренажних 
периода које се одвијају у циклусима (најчешће на 2, 3 или 4 недеље), али је такође истина да ове варијанте не прате периоди растерећења, чиме се губи валовитост оптерећења у правом смислу речи, што је један од предуслова за формирање средњих циклуса тренинга - мезоциклуса. Међутим, с обзиром на учестало посматрање експерименталног фактора кроз линеарно тренажно оптерећење, то ће се за потребе овог рада такав дизајн сматрати периодизованим моделом. Додатну забуну у анализираним радовима уносе и одређени аутори који овај модел називају традиционалним (Ullrich, Pelzer, \& Pfeiffer, 2018; Ullrich, Pelzer, Oliveira, \& Pfeiffer, 2016), односно традиционално линеарно периодизованим (Ноffman, Ratamess, Klatt, Faigenbaum, Ross, Tranchina, ... \& Kraemer, 2009), иако поменути модели немају периоде растерећења (што је основна карактеристика традиционалног модела). Са друге стране, има и примера када аутори дефинишу моделе периодизације као непериодизовани, линеарни и нелинеарни модел, иако се анализом сва три посматрана модела уочава да имају периоде повећања оптерећења (3 недеље) и растерећења (1 недеља) (Monteiro, Aoki, Evangelista, Alveno, Monteiro, da Cruz Piçarro, \& Ugrinowitsch, 2009), што би их дефинисало као варијанте традиционалног модела.

Поред модела где нема цикличних промена компоненти оптерећења, постоје и периодизовани модели (Periodized) код којих се ти циклуси у одређеном смислу уочавају. Те моделе карактеришу промене компоненти оптерећења, где се у односу на сврху, учесталост и величину тих промена јављају и различите варијанте. За потребе овог рада под периодизованим моделима ће се сматрати следећи модели периодизације и њихове варијације:

- линеарни модел периодизације - ЛП (Linear Periodization - LP);

- традиционални модел периодизације - ТП (Traditional Periodization - TP);

- блок модел периодизације - БП (Block Periodization - BP).

- таласасти модел периодизације - УП (Undulating Periodization - UP);

Под ЛП се пре свега подразумева његова прогресивна варијанта (интензитет се прогресивно мења) коју карактеришу велики обим и ниски интензитет рада на почетку програма тренинга вежбања. Током времена, компоненте оптерећења се мењају, односно обим постепено опада, а интензитет расте. Под ЛП се подразумева и друга варијанта програма тренажног оптерећења коју карактеришу мали обим и висок интензитет рада на почетку програма, где током времена обим постепено расте док се интензитет смањује. Оваква варијанта ЛП се назива обрнути линеарни модел (Reverse Linear Periodization - RLP) и погодна је за развој мишићне издржљивости и максималне јачине (Clemente-Suárez, Fernandes, Arroyo-Toledo, Figueiredo, González-Ravé, \& Vilas-Boas, 2015), при чему је важно пратити и анализирати резидуалне ефекте параметара снаге.

Традиционални модел периодизације карактерише таласаста прогресија, односно периоди надоптерећења ${ }^{1)}$ прожети периодима растерећења, где се вежбање на почетку програма поклапа са фазом опште припреме. Карактеришу га велики обим и ниски интензитет тренажног оптерећења, који се касније (фаза специфичне припреме) мења и усмерава ка малом обиму и високом интензитету (Kraemer \& Ratamess, 2004). Сличан је са ЛП, али за разлику од њега, има периоде растерећења (чини основ за постојање мезоциклуса) те се зато назива ТП (Strohacker et al., 2015). Код овог модела вежбања у пракси нема недоумица око програма тренинга и терминологије. Ради се о распрострањеном и применљивом моделу периодизације који је проистекао из јасно дефинисане теорије којој овај модел припада.

У БП програм тренинга се спроводи у блоковима (акумулација / трансформација / реализација) у којима је фокус на специфичним циљевима. Управо су мезоциклусни тренажни блокови и оличење блок периодизације као засебног концепта периодизације (Issurin, 2009), те из тог разлога, ни код овог модела нема никаквих недоумица, око класификације и терминологије.

У односу на ТП, УП карактерише учесталија промена компоненти оптерећења, али без промене укупне количине оптерећења (периоди растерећења) током програма тренинга - вежбања. У односуна њихову учесталост издваја се неколико

1) Надоптерећење се односи на примену режима тренинга са оптерећењем већим од оног на које је спортиста навикао (Baechle \& Earle, 2008). Пре свега у смислу стимулативног оптерећења - или комбинације одржавајућег и стимулативног; оптерећење које није неадекватно, односно које није преоптерећење које води у претренираност. 
варијанти овог модела. Најзаступљенија је дневна таласаста варијанта (Daily Undulating Periodization - DUP) коју карактеришу различити обими и интензитети у оквиру сваког појединачног тренинга или једне недеље. Недељну таласасту варијанту (Weekly Undulating Periodization - WUP) карактеришу промене обима и интензитета на недељном, односно двонедељном (2Weekly Undulating Periodization - 2WUP) нивоу. Такође, могућа је комбинација и појединих варијанти УП - дневне и недељне варијанте - где сваки тренинг у оквиру једне недеље подразумева другачији програм, али је и свака недеља другачија од претходних недеља. У пракси (погрешно) се сврстава у неку од већ постојећих варијанти УП. Могуће је уочити да се у дизајнима појединих истраживања, у њиховом самом експерименталном фактору јасно препознаје разлика између двонедељног УП и ЛП у коме се мењају оптерећења на две недеље (Tammam \& Hashem, 2016). Наиме, исправност у поставци експерименталног фактора проистиче из сензитивнијег приступа ефектима ЛП који се одвијају у једном правцу односа компоненти оптерећења (нпр. обим се стално смањује, а интензитет стално расте), док се код двонедељног УП тај однос такође мења на 2 недеље, али није увек у истом правцу. Нелинеарни модел периодизације (Non-Linear Periodization - NLP) је практично једна од варијанти таласастог приступа тренажном оптерећењу. Иако се често издваја као засебан (проблем терминологије), за потребе ове анализе, исти ће бити дефинисан као УП (Hoffman et al., 2009; Kraemer, Häkkinen, Triplett-McBride, Fry, Koziris, Ratamess, ... \& Gordon, 2003). Модел флексибилне нелинеарне периодизације (Flexible NonLinear Periodization - FNLP) је још једна варијанта УП. Карактерише га прилагодљивост тренажних активности на основу спремности (осећаја) вежбача, а по спољашњем изгледу периодизованог рада је веома сличан дневном УП. Дакле, наведени модели периодизације тренажног оптерећења, из разлога лакшег сагледавања утицаја, биће третирани као варијанте УП, што у својој суштини и јесу.

Имајући у виду да се под периодизацијом подразумева ефекат тренинга заснован на фазама и периодима његовог утицаја, очигледно је да периодизација не може бити линеарна или таласаста (Bompa \& Buzzichelli, 2018). Може се уочити да се у погледу смењивања укупне коли- чине оптерећења, као и постојања средњих циклуса, једино ТП и БП могу сматрати периодизованим моделима у правом смислу те речи. У том контексту, код ова два модела нема ни недоумица око терминологије. Велика недоследност у терминологији која води до грешке у поставци експерименталног фактора и закључивања по резултатима истраживачких модела, јавља се управо из разлога што се модели називају према облику или спољашњем изгледу периодизованог рада. Супротно томе, суштину за истраживачке пројекте треба да чини структура или унутрашњи изглед варијативности тренажног оптерећења и опоравка. Конкретно, код равномерне и насумичне варијанте (непериодизовани модел), односно код ЛП и УП (за ово истраживање сврстани у периодизоване моделе иако су практично и они непериодизовани), суштина - па и назив - је у спољашњем изгледу, док су код ТП и БП то свакако унутрашња структура и варијативност тренажног оптерећења и опоравка. Ипак, што се тиче овог рада, под непериодизованим моделом ће се сматрати насумича и равномерна варијанта, а под периодизованим моделима ТП и БП, али и ЛП и УП.

\section{Јачина и снага у теорији спортског тренинга}

У стручној и научној јавности, одавно се води дебата који је начин вежбања најприкладнији за унапређење јачине и снаге. С тим у вези, истраживан је утицај различитих модела периодизације на различите моторичке способности и карактеристике испитаника различитог хронолошког и тренажног узраста, као и нивоа тренираности. Иако преовладава мишљење да је примена периодизованих модела са циљем развоја јачине, снаге и мишићне издржљивости боља у односу на непериодизовани модел (Fleck, 1999; Herrick \& Stone, 1996; Kramer, Stone, O’bryant, Conley, Johnson, Nieman, ... \& Hoke, 1997; O’bryant, Byrd, \& Stone, 1988; Rhea \& Alderman, 2004; Stone, Potteiger, Pierce, Proulx, O’bryant, Johnson, \& Stone, 2000; Williams, Tolusso, Fedewa, \& Esco, 2017), одређена истраживања упућују на то да су користи од периодизације са циљем повећања јачине мишића и хипертрофије у великој мери утемељене на претпоставкама и да има мало необоривих доказа да је периодизација супериорнији план вежбања 
(Mattocks, Dankel, Buckner, Jessee, Counts, Mouser, ... \& Loenneke, 2016). Такође, закључује се да када се изједначе укупни обим и интензитет тренажног оптерећења, да тада нема разлика у примени непериодизованог и периодизованог модела (Baker, Wilson, \& Carlyon, 1994), односно да периодизовани модел не изазива увек значајна побољшања у поређењу са непериодизованим моделом (Grgic, Lazinica, Mikulic, \& Schoenfeld, 2018; Hoffman et al., 2009; Souza, Ugrinowitsch, Tricoli, Roschel, Lowery, Aihara, ... \& Wilson, 2014). Другим речима, не оспорава се нужно да су периодизовани модели супериорнији (постојање методолошког објашњења за варирање варијабли тренинга како би се оптимизовали исходи), али с обзиром на наведена ограничења експерименталног фактора, очигледно је да тренутно, на основу досадашњих истраживања, није могуће извући релевантне и валидне закључке у вези са овом темом (Nunes, Ribeiro, Schoenfeld, \& Cyrino, 2018). Неконзистентност у закључцима се јавља и у истраживањима у којима су се поредиле различите варијанте периодизованог тренинга, пре свега кроз линеарни и таласасти модел периодизације, и у којима се закључује да нема разлика између наведених модела вежбања (или периодизације?) (Buford, Rossi, Smith, \& Warren, 2007; Harries, Lubans, \& Callister, 2015; Grgic, Mikulic, Podnar, \& Pedisic, 2017). Анализом није могуће доћи до закључка да ли истраживачи дизајном својих истраживања теже да утврде да ли постоји разлика у ефектима између традиционалног и таласастог модела периодизација на посматране биомоторичке способности, пре свега мишићну јачину. Није могуће утврдити који је ефикаснији модел периодизованог програма експерименталног фактора јер су закључци неких претходних студија, на које се аутори позивају, показали да је таласасти модел бољи за развој јачине (процењену преко $1 \mathrm{RM})$, али не и снаге, мишићне издржљивости, изометријске јачине и мишићне хипертрофије (Caldas, Guimarães-Ferreira, Duncan, Leopoldo, Leopoldo, \& Lunz, 2016).

Непостојање јединственог става по питању теоријског и практичног контекста периодизације доводи до неконзистентних закључака о ефикасности различитих модела периодизације заснованих вероватно пре свега на грешкама у методологији која је коришћена у различитим истраживањима. Наиме, прегледом истраживања која су била обухваћена мета-анализама и увидом у реализоване програме тренинга у њима, уочена је пре свега одређена недоследност у називима модела периодизације. Из тог разлога, уколико би се модели поредили суштински, а не како су названи од стране аутора, за могло би се доћи до конкретнијих закључака (различито дефинисани модели периодизације, специфичност тренажних оптерећења, различите величине појединих компоненти оптерећења). Следећи, не толико безначајан чинилац, који детерминише могуће грешке у закључивању по експерименталном фактору, јесте мали узорак и нехомогеност испитаника када се сагледа по различитим критеријумима (пол, године, животни стил, ниво тренираности, историја тренинга). Имајући у виду специфичности тренинга и утицај промене метода вежбања на адаптацију, као и различито време трајања експерименталних фактора, претпоставља је да ће код различитих групација испитаника и одговор организма бити различит. Конкретно, ако се претпостави да је традиционални модел периодизације у спортској пракси заступљенији од неких других модела, што је потврђено у једном раду који је ту тему обрађивао (Junior \& Drigo, 2017), он ће бити у неравноправаном положају у односу на моделе који нису до тада примењивани код посматраних спортиста. Самим тим веома је тешко извести јединствен закључак о величини утицаја одређеног модела периодизације у односу на други. Предлог је да будуће студије треба да контролишу примену принципа специфичности ефеката вежбања, као и друге варијабле којима се гради спортска форма. Сходно томе, било би могуће правилно одредити да ли је систематска варијација оптерећења важна за максимизирање посматраних моторичких способности. Овоме у прилог говоре и закључци готово свих анализираних студија, а то је потреба даљих истраживања (Miranda, Simão, Rhea, Bunker, Prestes, Leite, ... \& Novaes, 2011; Moraes, Fleck, Dias, \& Simão, 2013; Rhea \& Alderman, 2004; da Silva, Vilaça-Alves, de Souza, dos Santos, \& Figueiredo, 2016; Storer, Dolezal, Berenc, Timmins, \& Cooper, 2014). Поставља се питање да пи је закључни исказ емпиријских напора о потреби будућих истраживања, израз методолошке неконзистентности, недовољне теоријско - практичне просвећености истраживача, недовољне структурираности истраживачких тимова свим просторима спортских наука, или недовољно промишљеним проблемом 
истраживања? Ако је одговор последња од управо наведених недоумица, то доводи у питање сврсисходност истраживања, а са тиме и сам процес закључивања по предмету и проблему!

Наведени недостаци би могли бити делимично решени сагледавањем суштинских карактеристика програма вежбања (без обзира како су га истраживачи дефинисали), али и одређеним хомогенизовањем узорка, односно сагледавањем утицаја различитих модела периодизације на испитанике који су по неком критеријуму хомогенизовани.

Проблем овог истраживања је проистекао из уочене теоријске и методолошке неконзистентности истраживача у простору дизајна истраживања и расправе о утицају различитих модела периодизације на јачину спортиста. Предметом истраживања обухваћене су публиковане студије које су у свом фокусу имале поређење утицаја примене различитих модела периодизације у тренингу јачине код спортиста. Циљ рада је да се анализом и утврђивањем чињеница методолошког и теоријског конструкта периодизације, разумеју закључци различитих истраживања, за које се може рећи да - и поред публиковања у значајним међународним часописима - воде до конфузије у простору закључивања о утицају различитих модела периодизације на јачину код спортиста. Истраживачки задаци су били: претраживање електронских база података, преглед и организовање прикупљених истраживања, дефинисање основних карактеристика програма, теоријска и анализа смисла дизајна студија и њихових резултата.

\section{МЕТОД РАДА}

\section{Узорак истраживачких студија}

У разматрање су узета истраживања која су за тему имала поређење утицаја примене различитих модела периодизације на јачину код спортиста. Електронско претраживање радова извршено је у следећим базама података: PubMed, ScienceDirect, SCIndex и Google Scholar. Претраживање је спроведено комбинацијом кључних речи везаних за периодизацију, тренинг јачине и спортисте. Претраживање је било ограничено на следеће појмове: „периодизација“, „јачина“, „снага“, „отпор“, „спорт“, „спортисти“, „тренинг“, „вежба“, „ефекти“, „обим“, „интензитет“, „оптерећење“, „поређење“, „утицај“, „перформансе“, и то претрагом на енглеском језику („periodization“, „strength“, „power“, „resistance”, „sport“, „athletes“, „training“, „exercise“, „effects“, „volume“, „intensity“, „load“, „comparison“, „influence“, „performance“). Прикупљено је и прегледано 84 рада који су објављени у научним часописима разврстаних на SCI листи у периоду од 2003. до 2018. године.

\section{Избор варијабли - дискриминативност анализираних истраживачких студија}

У предметним истраживачким студијама, унутар специфичности спортских грана у којима спортисти тренирају и такмиче, мерене су различите моторичке способности, карактеристике мишићног напрезања и тока адаптација (изометријска сила, јачина, снага, експлозивна снага, хипертрофија). Такође, у поступку доласка до закључака по предмету дизајна, примењивани су различити тестови, а ток истраживачких студија су пратиле и различите технике прикупљања података. Имајући у виду исказ, у скоро свим анализираним радовима, о потреби нових истраживања, за ово истраживање је извршен одабир - узорковање радова који садрже податке о варијаблама које су и прикупљене и представљене на такав начин да се недвосмислено могу међусобно поредити. Другим речима, учињен је искорак у разумевању смисла анализираних студија, а са циљем методолошких и терминолошких редукција претходних истраживања. Сходно предмету овог рада, одабрана су истраживања у којим су јасно дефинисане компоненте оптерећења, као и варијабле које описују јачину испитаника - максимална изометријска сила и/ или 1RM. Такође, код одабира експерименталног утицаја одабраних вежбања, критеријум је био да су вежбе релативно једноставне и широко распрострањене у тренингу јачине код спортиста. С тим у вези, за анализу утицаја експерименталних фактора на мишиће руку одабран је потисак са груди, док су за процену утицаја на мишиће ногу одабране две вишезглобне вежбе и то чучањ (различите дубине - углови у зглобовима колена) и потисак ногама, као и две једнозглобне вежбе и то опружање и прегибање зглоба колена. 


\section{Критеријуми за класификацију}

Након анализе више од 80 радова публикованих у референтним часописима, селекцијом у односу на теоријско-методолошки и контекст дедуктивног закључивања, овом анализом је издвојено 10 истраживања у којима је упоређен утицај примене различитих модела периодизације (кроз тренирање скоковима, слободним теговима или машинама са теговима) на јачину код спортиста испољену при вежбама рукама и/или ногама. Ова истраживања представљају контролисане рандомизиране и нерандомизиране студије искључиво са спортистима као испитаницима. У њима је примена различитих модела периодизације трајала најмање 4 недеље, не улазећи - за сада - у основно питање: да ли се у том случају анализирани модели вежбања уопште могу називати моделима периодизације? Такође, у обзир су узети резултати само оних студија у којима је био јасно дефинисан програм тренинга током експерименталног периода (објективност, проверљивост).

Наведене критеријуме, од 84 анализирана, испунило је свега 10 публикованих истраживања, и то: Манћада и сарадника (Manchado, CortellTormo, \& Tortosa-Martínez, 2018), Улриха и сарадника (Ullrich et al., 2018), Тамама и Хашема (Tammam \& Hashem, 2016), Улриха и сарадника (Ullrich et al., 2016), Франћинија и сарадника (Franchini, Branco, Agostinho, Calmet, \& Candau, 2015), Бартоломеја и сарадника (Bartolomei, Hoffman, Merni, \& Stout, 2014), Пеинтера и сарадника (Painter, Haff, Ramsey, McBride, Triplett, Sands, ... \& Stone, 2012), Хофмана и сарадника (Hoffman et al., 2009), Хофмана и сарадника (Hoffman, Wendell, Cooper, \& Kang, 2003), као и Кремера и сарадника (Kraemer et al., 2003). У њима је укупно 229 испитаника (168 мушкараца и 61 жена) у потпуности завршило истраживање. Утицај различитих модела периодизације је мерен, најчешће преко теста 1RM, а у неким случајевима и преко максималне вољне контракције у изометријским условима. Тестови којима је праћен утицај различитих модела периодизације су једноставне вежбе које су извршаване на изокинетичким машинама, на машинама са теговима или са слободним теговима, а одвијале су се као: потисак са груди (у 8 истраживања), чучањ (5), получучањ (3) од чега једном у изометријским условима, потисак ногама (1), опружање колена (3) од чега два пута у изометријским условима, као и прегибање ко- лена (2) од чега једном у изометријским условима. Ипак, у теоријском смислу, већина радова је показала редукције, јер су само у 4 анализирана рада називи примењених модела периодизације, самим тиме и планираним исходима тренинга, били у складу са приложеним програмом тренинга. Другим речима, теоријске редукције доводе до методолошких редукција, самим тиме и до дискутабилности резултата и закључака истраживања која за предмет имају праћење ефеката периодизованог вежбања. Разлог томе су коришћени погрешни називи или варијанте појединих модела или чак и модели периодизације. У поглављу Дискусија наведени су и конкретни програми и разлози сврставања примењених варијанти, односно модела периодизације у неку другу варијанту, односно модел.

\section{РЕЗУЛТАТИ}

Резултати ове студије указују на то да се од пет посматраних модела (непериодизовани, линеарни, традиционални, блок, таласасти), блок модел периодизације показао као потенцијално најбоље решење за развој јачине код спортиста. Наиме, у истраживању Бартоломеја и сарадника (Bartolomei et al., 2014), као и Манћада и сарадника (Manchado et al., 2018), блок модел је поређен са традиционалним и показао се као боље решење за јачање горњих екстремитета, док за доње није било разлике. Са друге стране, у истраживању Пеинтера и сарадника (Painter et al., 2012) блок модел је поређен са таласастим моделом и показао се као боље решење за јачање мишића ногу. Што се тиче линеарног и таласастог модела, у четири истраживања је утврђено да оба модела имају ефекат у смислу побољшања способности (Franchini et al., 2015; Tammam \& Hashem, 2016; Ullrich et al., 2018; Ullrich et al., 2016), док се у једном од њих таласасти модел периодизације показао и као значајно боље решење (Tammam \& Hashem, 2016). У два истраживања су поређени таласасти и непериодизовани модел. У једној нема разлика и закључак је да оба модела подједнако унапређују способности и руку и ногу (Kraemer et al., 2003), док у другом непериодизовани модел даје боље резултате код доњих, док код горњих екстремитета ни један модел не даје резултате (Hoffman et al., 2003). У једној студији су поређени таласасти, непериодизовани и линеарни модел, и закључак 
је да сви посматрани модели утичу на побољшање јачине и горњих и доњих екстремитета (Hoffman et al., 2009). Између посматраних модела нису уо- чене значајне разлике. У табели 1 је приказан преглед свих 10 издвојених истраживања.

Табела 1 Преглед истраживања утицаја различитих модела периодизације на јачину код спортиста.

\begin{tabular}{|c|c|c|c|c|}
\hline Студија & $\begin{array}{c}\text { Испитаници, } \\
\text { спортска грана, трајање }\end{array}$ & Посматране варијабле & $\begin{array}{c}\text { Поређени модели } \\
\text { (и назив модела } \\
\text { пре редукције) } \\
\text { периодизације }\end{array}$ & Закључак истраживања \\
\hline $\begin{array}{l}\text { Manchado et } \\
\text { al. (2018) }\end{array}$ & $\begin{array}{l}\mathrm{N}=11, \text { жене } \\
\text { • Рукомет } \\
\text { • } 16 \text { недеља, } 2 \text { х недељно }\end{array}$ & $\begin{array}{l}\text { • 1RM потисак са груди } \\
\text { • 1RM получучањ }\end{array}$ & БП vs ТП & $\begin{array}{l}\text { БП се показао као боље решење за } \\
\text { развој јачине горњих екстремитета, } \\
\text { док не постоји разлика код доњих. }\end{array}$ \\
\hline $\begin{array}{l}\text { Ullrich et al. } \\
\text { (2018) }\end{array}$ & $\begin{array}{l}\text { • } \mathrm{N}=22,12 \text { мушкараца и } \\
10 \text { жена } \\
\text { • Различите спортске } \\
\text { гране } \\
\text { - } 6 \text { недеља, } 3 \text { х недељно }\end{array}$ & $\begin{array}{l}\text { - Опружање колена } \\
\text { у изометријским } \\
\text { условима } \\
\text { при } 70^{\circ} / 90^{\circ} / 110^{\circ}\end{array}$ & $\begin{array}{c}\text { ЛП vs УП } \\
\text { (ТР vs DUP) }\end{array}$ & $\begin{array}{c}\text { Оба модела су подједнако ефикасна } \\
\text { за повећање јачине екстензора } \\
\text { ногу. Скокови (СМJ) са различитим } \\
\text { оптерећењима (0\%, } 15 \%, 30 \% \text { од масе } \\
\text { тела) су коришћени као средство за } \\
\text { развој снаге. }\end{array}$ \\
\hline $\begin{array}{l}\text { Tammam } \\
\text { \& Hashem } \\
(2016)\end{array}$ & $\begin{array}{l}\text { • N=16, мушкарци } \\
\text { • Одбојка } \\
\text { • } 12 \text { недеља, } 4 \text { х недељно }\end{array}$ & $\begin{array}{l}\text { • 1RM потисак са груди } \\
\text {-1RM получучањ } \\
\text { •1RM прегибање колена } \\
\text { • 1RM опружање колена }\end{array}$ & ЛП vs УП & $\begin{array}{c}\text { Након } 12 \text { недеља уочен значајан } \\
\text { напредак применом оба модела. } \\
\text { Такође, УП је у односу на ЛП } \\
\text { значајно ефикаснији код свих } \\
\text { посматраних варијабли, осим код } \\
\text { прегибања колена. }\end{array}$ \\
\hline $\begin{array}{l}\text { Ullrich et al. } \\
\text { (2016) }\end{array}$ & $\begin{array}{l}\text { • } \mathrm{N}=11,5 \text { мушкараца и } \\
6 \text { жена } \\
\text { • Џудо } \\
\text { • } 4 \text { недеље, } 3 \text { х недељно }\end{array}$ & $\begin{array}{l}\text { • 1RM потисак са груди } \\
\text { - 1RM чучањ } \\
\text { • Опружање колена } \\
\text { у изометријским } \\
\text { условима при } 70^{\circ} \\
\text { • Прегибање колена } \\
\text { у изометријским } \\
\text { условима при } 30^{\circ}\end{array}$ & $\begin{array}{l}\text { ЛП vs УП } \\
\text { (TP vs DUP) }\end{array}$ & $\begin{array}{c}\text { Након кратког временског периода } \\
\text { код оба модела су уочена побољшања } \\
\text { у максималној мишићној јачини и } \\
\text { горњих и доњих екстремитета. }\end{array}$ \\
\hline $\begin{array}{l}\text { Franchini et } \\
\text { al. (2015) }\end{array}$ & $\begin{array}{l}\text { • N=13, мушкарци } \\
\text { • Џудо } \\
\text { • } 8 \text { недеља, } 5 \text { х недељно } \\
\end{array}$ & $\begin{array}{l}\text { • 1RM потисак са груди } \\
\text { • 1RM чучањ }\end{array}$ & ЛП vs УП & $\begin{array}{c}\text { Слични ефекти побољшања } \\
\text { способности су уочени након } \\
\text { примене оба модела. } \\
\end{array}$ \\
\hline $\begin{array}{l}\text { Bartolomei et } \\
\text { al. (2014) }\end{array}$ & $\begin{array}{l}\text { - } \mathrm{N}=24, \text { мушкарци } \\
\text { • Бацачке дисциплине, } \\
\text { Рагби и Амерички } \\
\text { фудбал } \\
\text { - } 15 \text { недеља, } 4 \text { х недељно }\end{array}$ & $\begin{array}{l}\text { • 1RM потисак са груди } \\
\text { • Получучањ у } \\
\text { изометријским } \\
\text { условима }\end{array}$ & БП vs ТП & $\begin{array}{l}\text { БП се показао као боље решење за } \\
\text { развој јачине горњих екстремитета, } \\
\text { док не постоји разлика код доњих. }\end{array}$ \\
\hline $\begin{array}{l}\text { Painter et al. } \\
\text { (2012) }\end{array}$ & $\begin{array}{l}\text { - } \mathrm{N}=26,19 \text { мушкараца и } \\
7 \text { жена } \\
\text { - Атлетика } \\
\text { - } 10 \text { недеља, } 3 \text { х недељно }\end{array}$ & • 1RM чучањ & $\begin{array}{c}\text { БП vs УП } \\
\text { (BP vs DUP) }\end{array}$ & $\begin{array}{c}\text { БП показао већи утицај на } \\
\text { побољшање максималне јачине у } \\
\text { односу на УП. }\end{array}$ \\
\hline $\begin{array}{l}\text { Hoffman et } \\
\text { al. (2009) }\end{array}$ & $\begin{array}{l}\text { • N=51, мушкарци } \\
\text { • Амерички фудбал } \\
\text { • } 15 \text { недеља, } 4 \text { х недељно }\end{array}$ & $\begin{array}{l}\text { • 1RM потисак са груди } \\
\text { • 1RM чучањ }\end{array}$ & $\begin{array}{l}\text { НП vs ЛП vs УП } \\
\text { (NP vs PL/TPL vs } \\
\text { NLP) }\end{array}$ & $\begin{array}{c}\text { Применом сва три модела се значајно } \\
\text { унапређују и потисак са груди и } \\
\text { чучањ. Нема разлика између модела. }\end{array}$ \\
\hline $\begin{array}{l}\text { Hoffman et } \\
\text { al. (2003) }\end{array}$ & $\begin{array}{l}\text { • N=28, мушкарци } \\
\text { • Фудбал } \\
\text { • } 12 \text { недеља, } 2 \text { х недељно }\end{array}$ & $\begin{array}{l}\text { • 1RM потисак са груди } \\
\text { • 1RM чучањ }\end{array}$ & $\begin{array}{l}\text { НП vs УП } \\
\text { (LP vs NLP) }\end{array}$ & $\begin{array}{c}\text { Током сезоне, уочен је значајан } \\
\text { напредак применом само НП модела } \\
\text { и то у чучњу. Ни један посматрани } \\
\text { модел није дао значајан напредак у } \\
\text { потиску са груди. } \\
\end{array}$ \\
\hline $\begin{array}{l}\text { Kraemer et } \\
\text { al. }(2003)\end{array}$ & $\begin{array}{l}\text { • } \mathrm{N}=27, \text { жене } \\
\text { • Тенис } \\
\text { • } 9 \text { месеци, } 3 \text { х недељно }\end{array}$ & $\begin{array}{l}\text { • 1RM потисак са груди } \\
\text { • 1RM потисак ногама }\end{array}$ & $\begin{array}{l}\text { УП vs НП } \\
\text { (NLP vs NP vs } \\
\text { Control) }\end{array}$ & $\begin{array}{c}\text { Применом оба модела се након } \\
9 \text { месеци значајно унапређују и } \\
\text { потисак са груди и чучањ. }\end{array}$ \\
\hline
\end{tabular}




\section{ДИСКУСИЈА}

Пре дискусије о разлозима теоријских редукција, као и о резултатима студије (након редукција), потребно је изнети одређена запажања која се тичу валидности резултата анализираних истраживања. Има их неколико:

1. Варијативност тренажног оптерећења током трајања протокола експеримента. Већ при првој класификацији на непериодизоване и периодизоване моделе тренажног плана, долази се до првих теоријских и методолошких недоумица. Наиме, поставља се питање да ли су постојали периоди растерећења као постулат и суштина самог концепта периодизације, односно да ли је методолошки исправно линеарни и таласасти модел периодизације (који су за ово истраживање сврстани у периодизоване моделе, иако су практично непериодизовани) разликовати од стварно непериодизованог модела (равномерне и насумичне варијанте), или је исправно посматрати их као и традиционални и блок модел периодизације (који су периодизовани у правом смислу речи; по свим критеријумима)?

2. Дизајни анализираних студија не садрже наводе о моделу периодизације које су спортисти користили пре деловања експерименталних фактора. У том контексту, могло би се претпоставити да ће сама промена режима тренирања проузроковати различит степен биомоторичких, енергетских и координационих адаптација, те уколико је већ неко време тренирано по одређеном моделу, може се очекивати да ће наставак вежбања по истом моделу имати смањен одговор (акомодација). Самим тим, закључци би ишли на штету оних модела који су најчешће примењивани, односно ако је претпоставка да је у спортској пракси најзаступљенији традиционални модел периодизације, очигледно је да би се управо овај модел периодизованог тренинга показао као мање ефикасан, него што то можда стварно јесте.

3. Нејасно дефинисани чиниоци који могу утицати на ефикасност модела периодизације (декларисаног или стварног). То су пре свега специфичност оптерећења и укупни обим рада, али и период у сезони, као и етапе каријере у којој је примењивано експериментално вежбање (фактор). Такође, и трајање експерименталног фактора је још један од администрираних критеријума који својим непрограмираним трајањем свакако утиче на сензитивност процеса, а самим тим и на сам процес сазнања. До сличних запажања су дошли и други аутори, односно у закључку по овој анализи, важно је истаћи да исходи експеримената нису анализирани и проверени у односу на постављене хипотезе, односно да су саме анализе већином биле једнодимензионалне, те да су уочене и друге методолошке недоследности, пре свега око интегралности реакције испитаника на тренажне стимулусе (Afonso, Nikolaidis, Sousa, \& Mesquita, 2017). Такође, према Афонсу и сарадницима дискутабилни су и концепти периодизације, али и потреба аутора да варирања компоненти оптерећења користе као синоним за периодизацију. У таквом контексту експерименталног дизајна се долази до суштинског методолошког проблема, а он је да декларисани модели периодизације то у ствари нису, јер се под периодизацијом биомоторичких способности подразумева да се „циљеви, садржаји и методе програма тренинга јачине мењају током фаза тренажног плана који се најчешће веже за тренажну годину“ (Вотра, 2009). Практично, за краће периоде циклуса тренинга не би требало користити термин „периодизација“, већ би на овом месту можда била прикладнија употреба термина „тренажне адаптације у односу на метод и садржај тренинга“. Неадекватност примене термина „периодизација“ у поменутом контексту, још је очигледнија ако периодизацију посматрамо у ширем контексту - као стратегију планирања тренажних активности која води свеукупној трансформацији и интегралном оптимизовању свих потенцијала спортисте за наступ на циљаном такмичењу.

4. Примена константне величине тренажног оптерећења код линеарног (промена обима коју прати промена интензитета) и непериодизованог (равномерна варијанта) модела тренинга (константне вредности обима и интензитета). Имајући у виду да аутори наглашавају (Kraemer et al., 2003, Hoffman et al., 2009) да је код непериодизованог модела оптерећење прилагођавано на сваком тренингу, односно да је сугерисано да се истим максималним напором извршавају последња предвиђена понављања, очигледно је да се оптерећење у апсолутним вредностима током деловања експерименталног фактора ипак повећавало. Самим тим, ипак има одређене про- 
мене са унутрашњег аспекта адаптација, те у неком смислу није у потпуности равномеран. Сходно томе, у одређеним специфичним ситуацијама има унутрашњу структуру сличну линеарном моделу (обим понављања до „отказа“ са субјективним осећајем вежбача). Имајући наведено у виду, а с обзиром на то да ни линеарни ни равномерни модел немају периоде растерећења, оправдано би било посматрати их као варијанте непериодизованог модела.

\section{Примери дизајна и теоријског полазишта - разлози за редукцију}

У истраживању Манћада и сарадника (Manchado et al., 2018) поређени су традиционални и блок модел периодизације где су рукометашице једне сезоне у припремном периоду тренирале по традиционалном моделу периодизације, док су наредне сезоне у припремном периоду тренирале по блок моделу. Код оба модела је цео програм вежбања са циљем развоја јачине (али и са циљем развоја издржљивости) спроведен кроз 3 фазе (мезоциклуса - МЗЦ) и то за традиционални модел: генералне припреме, специфичне припреме и такмичења; односно за блок модел кроз фазе: акумулације, трансформације и реализације. Прве фазе у оба модела су подразумевале рад на развоју јачине, где је током 4 недеље код традиционалног модела програм вежбања предвиђао рад у 3 серије по 10 понављања на 60\% од 1RM (1. недеља), у 3 серије по 10 понављања на 65\% од 1RM (2. недеља), у 3 серије по 9 понављања на 70\% од 1RM (3. недеља), у 3 серије по 8 понављања на 75\% од 1RM (4. недеља), док је код блок модела током свих 5 недеља (једна недеља дуже!) подразумевао вежбање са мањим бројем понављања - од 1 до 4 - али са интензитетом између 80\% и 95\% од 1RM. Током друге фазе, у оба посматрана модела, фокус је био на развоју снаге. Код традиционалног модела је програм током прве три недеље подразумевао рад са 5 до 6 понављања при интензитету од $75 \%$ до $85 \%$ од $1 \mathrm{RM}$, а током последње недеље при 50\% до 60\% од 1RM (растерећење), док je са друге стране код блок модела подразумевао током свих 5 недеља (поново једна недеља дуже!) максималну брзину извођења при интензитету од 75\% до 80\% од 1RM. Трећа фаза је подразумевала рад на развоју специфичне снаге потребне за рукомет и то током 8 недеља код традиционалног, a 6 недеља код блок модела (две недеље краће!). Имајући у виду да постоје одређене промене укупног оптерећења, сматраће се да су приказани модели названи одговарајућим именима. Са друге стране, иако оба модела трају исто, проблем је у неједнаком трајању фаза током којих је деловао одређени експериментални фактор. Чак и сами аутори наводе да су током прве фазе по оба модела, вежбања спровођена коришћењем истих вежби у истом недељном обиму тренинга, а да је разлика само у интензитету и обиму.

У истраживању Улриха и сарадника (Ullrich et al., 2018) традиционални модел је подразумевао да се интензитет повећавао на сваке 2 недеље - у 1. и 2. недељи у 6 серија по 7 скокова са $0 \%$ од масе тела (1. тип тренинга); у 3. и 4. недељи у 6 серија по 5 скокова са 15\% од масе тела (2. тип тренинга); у 5. и 6. недељи у 6 серија по 3 скока са 30\% од масе тела (3. тип тренинга) - што је карактеристика линеарног модела из разлога што нема периоде растерећења, а обим опада и интензитет расте. Из тог разлога, за потребе овог рада исти је посматран као линеарни модел. Са друге стране, дневни таласасти модел је подразумевао да је свака недеља имала различит редослед тренинга са различитим оптерећењима $(1,2$. и 3 . тип тренинга), тако да је он и посматран као таласасти модел.

У истраживању Тамама и Хашема (Tammam \& Hashem, 2016) називи модела периодизације су у складу са терминологијом коришћеном у овом раду. Наиме, код линеарног (прогресивног) модела, програмом вежбања је од 1. до 3. недеље предвиђен рад у 3 серије по 10RM (10 максималних понављања), од 4. до 6. недеље у 3 серије по 8RM, од 7. до 9. недеље у 3 серије по 6RM, и од 10. до 12. недеље у 3 серије по 4RM. Код двонедељног нелинеарног (у оригиналном раду) програмом вежбања је у 1. и 2. недељи предвиђен рад у 3 серије по 10RM, у 3. и 4. недељи у 3 серије по $8 \mathrm{RM}$, у 5. и 6. недељи у 3 серије по $4 \mathrm{RM}$, у 7. и 8. недељи у 3 серије по 10RM, у 9. и 10. недељи у 3 серије по 6RM, и у 11. и 12. недељи у 3 серије по 4RM, што карактерише управо наведени модел периодизације, те је он у овом раду и посматран као варијанта таласастог модела.

У још једном истраживању Улриха и сарадника (Ullrich et al., 2016) уочава се недоследност у називима модела. Наиме, под традиционалним моделом се подразумева начин вежбања, где се након 4 тренинга смањивао интензитет вежбања. 
Конкретно за вежбу чучањ, на прва 4 тренинга (T1, T2, T3, T4) програм вежбања је подразумевао рад у 3 серије по 1 до 2 понављања са $80 \%$ до 90\% од 1RM (зона јачине); од Т5 до Т8 у 3 серије по 1 до 4 понављања са 65\% до 75\% од 1RM (зона снаге); од Т9 до Т12 у 3 серије по 3 до 6 понављања са $50 \%$ до $60 \%$ од 1RM (зона брзине). Слично је било и за вежбе потисак са груди и прегибање зглоба колена, само са другачијим бројем понављања при истим интензитетима од 1RM (и зонама). Beћ на први поглед се уочава да је у питању линеарни (обрнути) модел, а не традиционални, како је наведено. Иако је за све вежбе (па и за 3 издвојене у овом раду) на одређеним тренинзима долазило до благог растерећења, најчешће у виду смањења једног понављања у односу на претходни тренинг (за чучањ на Т4, Т8 и на Т12; по 1 понављање), те се овакав начин рада наизглед могао дефинисати као традиционални модел, ипак то није учињено jep је растерећење такво да се спроводи у оквиру истог микроциклуса (МЦ), односно нема периода тренирања са смањеним оптерећењем (има само по један тренинг, не и цео МЦ).

У истраживању Франћинија и сарадника (Franchini et al., 2015) поређен је линеарни (обрнути) модел са таласастим моделом периодизације. Код линераног модела, програм вежбања је подразумевао да се током прве 2 недеље вежба у 4 серије по 3 до 5 понављања (1. тип тренинга), током наредне 3 недеље у 4 серије по 6 до 8 понављања на $80 \%$ од $1 \mathrm{RM}$ (2. тип тренинга), a током последње 3 недеље по 15 до 20 понављања (3. тип тренинга). Код таласастог модела програм вежбања је подразумевао такође 3 тренинга недељно и то по једном недељно сваки од 3 различита типа тренинга. У наредним недељама је мењан само њихов распоред унутар недеље, осим у 5. и 7. недељи када је уместо типа тренинга са 3 до 5 понављања, понављан тип тренинга са 6 до 8 понављања на $80 \%$ од 1RM (понедељак и петак), односно тип тренинга са 15 до 20 понављања (понедељак и петак). Аутори су у оба модела користили терминологију која је у складу са терминологијом коришћеном у овом раду.

У истраживању Бартоломеја и сарадника (Bartolomei et al., 2014) поређени су традиционални модел и блок модел периодизације. Код традиционалног модела, програм вежбања је подразумевао 3 МЗЦ који су трајали по 5 недеља (очигледно аутори - не само у наведеном раду - уместо термина микроциклус, користе термин недеља!) са по 2 тренинга недељно на којима је примењиван експериментални фактор (програм је подразумевао 4 тренинга недељно за развој јачине, али је било само 2 вежбе за оне које су посматране у овом раду). У сва 3 МЗЦ редослед недеља је био исти - у 1. недељи у 5 серија по 8 до 10 понављања сa $65 \%$ до $75 \%$ од $1 \mathrm{RM}$; у 2 . недељи у 5 серија по 5 до 6 понављања са 75\% до 85\% од 1RM; у 3. недељи у 5 серија по 3 до 4 понављања са $85 \%$ до 95\% од $1 \mathrm{RM}$; $\mathrm{y}$. недељи са 50\% до 60\% од 1RM; у 5. недељи рад са малим оптерећењем и то кроз само 2 тренинга (растерећење). Практично, програм је подразумевао понављање линеарног прогресивног модела са растерећујућом последњом недељом, где су се апсолутне вредности оптерећења (y kg) прилагођавале реалном стању вежбача (повећање апсолутног оптерећења да би интензитет остао у предвиђеним оквирима). Код блок модела, програм вежбања је подразумевао исти број МЗЦ, као и недеља и појединачних тренинга током њих као и код традиционалног модела. Програм вежбања у 1. МЗЦ је предвиђао рад на мишићној хипертрофији (акумулација) и то интензитетом од $65 \%$ до 75\% од 1RM кроз 6 до 10 понављања, затим рад на јачини (трансформација) током 2. МЗЦ и то интензитетом од 80\% до 95\% од 1RM кроз 1 до 6 понављања, и на крају током 3. МЗЦ је програм вежбања предвиђао рад на снази (реализација) и то интензитетом од 50\% до 65\% од 1RM кроз максималну брзину извођења. Имајући у виду да је и код блок модела на крају сваког МЗЦ предвиђена недеља растерећења, очигледно је да се оба модела могу класификовати како су их аутори и назвали традиционални модел и блок модел.

У истраживању Пеинтера и сарадника (Painter et al., 2012) поређен је блок модел са (дневним) таласастим моделом периодизације. У блок моделу, кроз 3 блока (за развој издржљивости, јачине и снаге) је манипулисано обимом и интензитетом како унутар, тако и током недеља, док је код (дневно) таласастог модела промена вршена само унутар недеље (1. тренинг у 3 серије по 8 до 12 понављања; 2. тренинг у 3 серије по 5 до 7 понављања; 3. тренинг у 3 серије по 3 до 5 понављања) где је исти садржај недеље понављан током целог периода. Ако се анализирају недеље (као МЦ), може се уочити да у прве 4 недеље, почетно недељно оптерећење расте, док у последњој оно пада. Даље, у наредне 4 недеље је понављан 
исти модел. Иако се у табелама у оригиналном раду наводи да је у питању традиционални, очигледно је да се појам „традиционални“ користио са значењем „уобичајени“, те је из тог разлога и посматран као блок модел.

У истраживању Хофмана и сарадника (Hoffman et al., 2009) називи модела периодизације нису у потпуности у складу са терминологијом коришћеном у овом раду. Током 4 тренинга снаге недељно, наизменично су на по 2 тренинга извођени потисак са груди и чучањ. Код непериодизованог модела предвиђен је рад у по 4 серије (5 серија у последње 4 недеље) по 6 до 8 понављања током целог периода. Тај назив одговара коришћеној терминологији у овом раду. Код традиционалног линеарног модела (како га аутори називају) током прве 4 недеље је предвиђено да се вежба у 4 серије по 9 до 12 понављања, па током наредних 6 недеља у по 4 серије по 6 до 8 понављања и током последње 4 недеље у по 5 серија по 3 до 5 понављања. Очигледно је да је у питању линеарни модел, никако традиционални. Такође, код нелинеарног модела током прве 4 недеље рад је предвиђао 4 серије по 3 до 5 понављања на једном и 9 до 12 понављања на другом тренингу те недеље (за чучањ обрнуто), па током наредних 6 недеља исто у 4 серије по 3 до 5 понављања на једном и 9 до 12 понављања на другом тренингу те недеље (за чучањ обрнуто), али са другачијим распоредом осталих вежби, и током последње 4 недеље у 5 серија по 3 до 5 понављања на једном и 9 до 12 понављања на другом тренингу те недеље (за чучањ обрнуто). Све карактерише управо наведени модел периодизације, те је он у овом раду и посматран као варијанта таласастог модела.

У још једном истраживању Хофмана и сарадника (Hoffman et al., 2003) називи модела периодизације нису у складу са терминологијом коришћеном у овом раду. Наиме, 4 вежбе набачај, чучањ, избачај, потисак са груди - су примењиване 2 пута недељно током 12 недеља. Линеарни модел је представљало вежбање током недеље на два идентична тренинга и то са $80 \%$ од $1 \mathrm{RM}$ и у обиму од по 3 серије са понављањима од 3 до 5 за набачај, од 6 до 8 за чучањ, од 4 до 6 за избачај, односно од 6 до 8 за потисак са груди. Овакав назив не одговара коришћеној терминологији у овом раду јер се током свих 12 недеља спроводи исти програм на свим тренинзима. Из тог разлога ово је пре равномерни непериодизовани модел, а не линеарни јер је очигледно да - посматрано за сваку вежбу посебно - нема варирања спољашњих компоненти оптерећења. Код нелинеарног модела примењиване су исте вежбе 2 пута недељно, али са различитим оптерећењима. Једном недељно интензитетом од 70\% од 1RM и у обиму од по 3 серије са понављањима од 4 до 6 за набачај, од 8 до 10 за чучањ, од 4 до 6 за избачај, односно од 8 до 10 за потисак са груди. Други тренинг у недељи је спровођен према програму који је подразумевао интензитет вежбања од 90\% од 1RM са обимом од по 3 серије са понављањима од 2 до 4 за све вежбе. Све карактерише управо наведени модел периодизације, те је он у овом раду и посматран као варијанта таласастог модела.

У истраживању Кремера и сарадника (Kraemer et al., 2003) код непериодизованог модела је током целог периода вежбано са таквим оптерећењима да је било могуће да се у 3 серије изведе по 8 до 10 понављања, док је при нелинеарном моделу интензитет мењан на сваком тренингу током недеље (понедељком у 3 серије по 4 до 6 понављања, уторком у 3 серије по 8 до 10, а петком у 3 серије по 12 до 15 понављања). Из тог разлога је у овом раду нелинеарни модел посматран као (дневни) таласасти модел. На овом месту важно је напоменути да су у оба модела оптерећења дефинисана по спољашњим карактеристикама, али да су се током трајања експерименталног фактора повећавала у апсолутним вредностима.

Уколико се погледа време публиковања радова код којих је дошло до промене назива примењених модела периодизације (услед несклада са приложеним програмом вежбања), може се закључити да су последњих година аутори донекле увидели проблеме на које је у овом раду указано, те је потреба за корекцијама терминолошких недоследности смањена. Ипак, да би се дискутабилност резултата и закључака истраживања која за предмет имају праћење ефеката периодизованог вежбања потпуно отклонила, потребно је прецизно дефинисати теоријски, али и методолошки оквир истраживања који ће бити објективан, сврсисходан и проверљив.

Поред неопходности уважавања запажања наведених на почетку поглавља Дискусија (друго и треће запажање), један од првих корака ка јаснијем дефинисању поменутих оквира, свакако би могло бити и поједностављење класификације 
модела по основном критеријуму - постојање или непостојање периода растерећења, односно варијативности тренажног оптерећења (прво запажање). Наиме, иако различите варијанте програмираног вежбања подразумевају релативно сличне варијације компоненти оптерећења (пре свега обима и интензитета), оне се у својој суштини разликују по томе да ли се укупно оптерећење током времена мења или се не мења. У том контексту, иако садрже сегменте који могу бити идентични линеарном или таласастом моделу (па и равномерном), традиционални и блок модел се класификују као периодизовани модели. Са друге стране, линеарни и таласасти модел карактерише константна инверзна међузависност компоненти оптерећења, чиме се одржава релативно слична величина оптерећења током целог периода трајања програмираног вежбања. У том контексту могуће је правити велики број варијација (линеарне, обрнуто линеарне, таласасте на дневном или недељном нивоу, итд.) или их чак изоставити (равномерни модел), али ће суштина остати иста - компоненте оптерећења се ни у једном тренутку не смањују истовремено, већ смањење једне, прати повећање друге. То за последицу има да се оптерећење надовезује на оптерећење што је могуће само у релативно кратким временским периодима. Имајући у виду да периодизација као концепт - између осталог - подразумева дуже временске периоде, као и варирање укупног тренажног оптерећења током њих, очигледно је да се поменути модели међусобно суштински разликују.

Оправдање за овакав покушај класификације модела - на периодизоване и непериодизоване - поред наведеног теоријског објашњења, донекле би могли да чине и резултати ове студије. Наиме, блок модел је једини модел који ни у једном истраживању није био лошије решење за унапређење посматраних способности од неког другог модела. Једино где није дао боље ефекте - већ исте - је у поређењу са традиционалним моделом, и то за мишиће ногу. Са друге стране, посматрајући остале моделе (линеарни, таласасти, непериодизовани) очигледно је да се и са таквим начином рада унапређују способности, али се не може са сигурношћу утврдити који је оптимално решење (можда зато што међу њима ни нема разлике). На крају, у само једном истраживању је поређен блок модел са таласастим моделом (периодизовани са непериодизованим), где се блок показао као боље решење. У последњој констатацији и леже разлози и оправдање за класификацију на само две класе модела - периодизоване и непериодизоване. Такође, традиционални модел није поређен ни са једним другим, осим са блок моделом (и то у два истраживања) те је и то чињеница коју је потребно имати на уму. У сваком случају, и по овом питању су потребна додатна истраживања - пре свега поређење утицаја традиционалног у односу на друге моделе - али засигурно са другачијим теоријским полазиштем, него што је до сада био случај у радовима који су обрађивали ову тему.

\section{ЗАКЉУЧАК}

Блок периодизација је потенцијално најбоље решење за развој јачине код спортиста. Овакав закључак се неметнуо након вишестране анализе великог броја публикованих радова у категорисаним научним часописима, а који се својим предметом и проблемом могу повезати са кључним речима овог рада (периодизација / мишићна јачина / сазнајна парадигма / методолошка редукција / научна периодика). Када је у питању јачина ногу, подједнако добро решење је и примена традиционалног модела периодизације. Са друге стране, блок модел се показао као значајно бољи од таласастог, што отвара могућност да се - посредно - могу донети и други афирмативни закључци о значају овог модела (али и периодизованих модела генерално) на развој посматраних моторичких способности код спортиста. Такође, и применом осталих модела (суштински непериодизованих, код којих нема варирања укупног оптерећења у посматраном периоду) се унапређује јачина код спортиста, али се не може утврдити који је модел рада оптимално решење.

Са друге стране, након теоријске и анализе смисла, значења и примењеног методолошког оквира, очигледно је да постоји потреба да се у научним часописима и публикованим радовима јасно дефинишу модел/и периодизације који ће се користити, односно одговорити на ово питање пре саме поставке експерименталног протокола.

Пре свега дискутабилни су концепти периодизације и употреба варирања (краткотрајног) компоненти оптерећења као синонима 
за периодизацију. Затим, ту су критеријуми за класификацију модела и то у смислу постојања или непостојања периода растерећења (промене укупне количине оптерећења). На ваљаност закључака свакако могу утицати и модели периодизације који су спортисти користили пре деловања експерименталних фактора, где се потенцијално фаворизују они модели који до тада нису примењивани из разлога што наставак вежбања по истом моделу може имати смањен одговор (акомодација). Такође и други чиниоци могу утицати на ефикасност модела периодизације, те је и њих потребно јасније дефинисати - специфичност оптерећења, обим рада, период у сезони или етапа у каријери, интегралност реакције на укупне тренажне стимулусе, као и трајање експерименталног фактора.

\section{ЛИТЕРАТУРА}

1. Afonso, J., Nikolaidis, P. T., Sousa, P., \& Mesquita, I. (2017). Is Empirical Research on Periodization Trustworthy? A Comprehensive Review of Conceptual and Methodological Issues. Journal of Sports Science and Medicine, 16(1), 27-34.

2. Baechle, T. R., \& Earle, R. W. (2008). Essentials of strength training and conditioning, 3rd edition. Human kinetics.

3. Baker, D., Wilson, G., \& Carlyon, R. (1994). Periodization: The effect on strength of manipulating volume and intensity. The Journal of Strength and Conditioning Research, 8(4), 235-42.

4. Bartolomei, S., Hoffman, J. R., Merni, F., \& Stout, J. R. (2014). A comparison of traditional and block periodized strength training programs in trained athletes. The Journal of Strength and Conditioning Research, 28(4), 990-997.

5. Bompa, T. O. (2009). Periodizacija: teorija $i$ metodologija treninga. Zagreb: Gopal.

6. Bompa, T. O., \& Buzzichelli, C. (2018). Periodization: Theory and Methodology of Training. Human Kinetics.

7. Bompa, T. O., \& Haff, G. G. (2009). Periodization: Theory and Methodology of Training, 5th edition. Human Kinetics.

8. Buford, T. W., Rossi, S. J., Smith, D. B., \& Warren, A. J. (2007). A comparison of periodization mod-
Уредници научних часописа и уредници секција, као и рецензенти, морају обратити пажњу на теоријске оквире студија из којих ће се, у наредном кораку, изнедрити методолошки оквир истраживања који ће бити објективан, сврсисходан, проверљив... На путу сазнања и закључака о току адаптација органских система као одговор на специфичност дизајна истраживачког протокола, потребно је да аутори поставе протокол који је сензитиван на проблем и циљ истраживања. Другим речима, исти мора бити без теоријских редукција које воде до методолошких недоследности и ка ниској примењивости у практичном раду у програмираној физичкој активности и спорту.

els during nine weeks with equated volume and intensity for strength. The Journal of Strength and Conditioning Research, 21(4), 1245-1250.

9. Caldas, L. C., Guimarães-Ferreira, L., Duncan, M. J., Leopoldo, A. S., Leopoldo, A. P. L., \& Lunz, W. (2016). Traditional vs. undulating periodization in the context of muscular strength and hypertrophy: a meta-analysis. International Journal of Sports Science, 6, 219-229.

10. Clemente-Suárez, V. J., Fernandes, R. J., ArroyoToledo, J. J., Figueiredo, P., González-Ravé, J. M., \& Vilas-Boas, J. P. (2015). Autonomic adaptation after traditional and reverse swimming training periodizations. Acta Physiologica Hungarica, 102(1), 105-113.

11. DeWeese, B. H., Gray, H. S., Sams, M. L., Scruggs, S. K., \& Serrano, A. J. (2013). Revising the definition of periodization: merging historical principles with modern concern. Olympic Coach, 24(1), 5-19.

12. Fleck, S. J. (1999). Periodized strength training: a critical review. The Journal of Strength and Conditioning Research, 13(1), 82-89.

13. Franchini, E., Branco, B. M., Agostinho, M. F., Calmet, M., \& Candau, R. (2015). Influence of linear and undulating strength periodization on physical fitness, physiological, and performance 
responses to simulated judo matches. The Journal of Strength and Conditioning Research, 29(2), 358367.

14. Grgic, J., Mikulic, P., Podnar, H., \& Pedisic, Z. (2017). Effects of linear and daily undulating periodized resistance training programs on measures of muscle hypertrophy: a systematic review and meta-analysis. PeerJ, 5, e3695.

15. Grgic, J., Lazinica, B., Mikulic, P., \& Schoenfeld, B. J. (2018). Should resistance training programs aimed at muscular hypertrophy be periodized? A systematic review of periodized versus nonperiodized approaches. Science \& Sports, 33(3), 97-104.

16. Haff, G. G., \& Triplett, N. T. (2015). Essentials of Strength Training and Conditioning 4th edition. Human Kinetics.

17. Harries, S. K., Lubans, D. R., \& Callister, R. (2015). Systematic review and meta-analysis of linear and undulating periodized resistance training programs on muscular strength. The Journal of Strength and Conditioning Research, 29(4), 1113-1125.

18. Herrick, A. B., \& Stone, W. J. (1996). The effects of periodization versus progressive resistance exercise on upper and lower body strength in women. The Journal of Strength and Conditioning Research, 10(2), 72-76.

19. Hoffman, J. R., Ratamess, N. A., Klatt, M., Faigenbaum, A. D., Ross, R. E., Tranchina, N. M., ... \& Kraemer, W. J. (2009). Comparison between different off-season resistance training programs in Division III American college football players. The Journal of Strength and Conditioning Research, 23(1), 11-19.

20. Hoffman, J. R., Wendell, M., Cooper, J., \& Kang, J. (2003). Comparison between linear and nonlinear in-season training programs in freshman football players. Journal of Strength and Conditioning Research, 17(3), 561-565.

21. Issurin, V. (2009). Blok periodizacija: Prekretnica u sportskom treningu. Beograd: Data Status.

22. Junior, A. C. T., \& Drigo, A. J. (2017). Application of training periodization models by elite judo coaches. Archives of Budo, 13(1), 139-146.

23. Kraemer, W. J., \& Ratamess, N. A. (2004). Fundamentals of resistance training: progression and exercise prescription. Medicine and Science in Sports and Exercise, 36(4), 674-688.

24. Kraemer, W. J., Häkkinen, K., Triplett-McBride, N. T., Fry, A. C., Koziris, L. P., Ratamess, N. A., ... \& Gordon, S. E. (2003). Physiological changes with periodized resistance training in women tennis players. Medicine \& Science in Sports \& Exercise, 35(1), 157-168.

25. Kramer, J. B., Stone, M. H., O'bryant, H. S., Conley, M. S., Johnson, R. L., Nieman, D. C., ... \& Hoke, T. P. (1997). Effects of single vs. multiple sets of weight training: impact of volume, intensity, and variation. Journal of Strength and Conditioning Research, 11, 143-147.

26. Manchado, C., Cortell-Tormo, J. M., \& TortosaMartínez, J. (2018). Effects of Two Different Training Periodization Models on Physical and Physiological Aspects of Elite Female Team Handball Players. The Journal of Strength and Conditioning Research, 32(1), 280-287.

27. Mattocks, K. T., Dankel, S. J., Buckner, S. L., Jessee, M. B., Counts, B. R., Mouser, J. G., ... \& Loenneke, J. P. (2016). Periodization: what is it good for? Journal of Trainology, 5(1), 6-12.

28. Miranda, F., Simão, R., Rhea, M., Bunker, D., Prestes, J., Leite, R. D., ... \& Novaes, J. (2011). Effects of linear vs. daily undulatory periodized resistance training on maximal and submaximal strength gains. The Journal of Strength and Conditioning research, 25(7), 1824-1830.

29. Monteiro, A. G., Aoki, M. S., Evangelista, A. L., Alveno, D. A., Monteiro, G. A., da Cruz Piçarro, I., \& Ugrinowitsch, C. (2009). Nonlinear periodization maximizes strength gains in split resistance training routines. The Journal of Strength and Conditioning Research, 23(4), 1321-1326.

30. Moraes, E., Fleck, S. J., Dias, M. R., \& Simão, R. (2013). Effects on strength, power, and flexibility in adolescents of nonperiodized vs. daily nonlinear periodized weight training. The Journal of Strength \& Conditioning Research, 27(12), 33103321.

31. Nunes, J. P., Ribeiro, A. S., Schoenfeld, B. J., \& Cyrino, E. S. (2018). Comment on: "Comparison of Periodized and Non-Periodized Resistance Training on Maximal Strength: A Meta-Analysis". Sports Medicine, 48(2), 491-494. 
32. O’bryant, H. S., Byrd, R., \& Stone, M. H. (1988). Cycle ergometer performance and maximum leg and hip strength adaptations to two different methods of weight-training. The Journal of Strength and Conditioning Research, 2(2), 27-30.

33. Painter, K. B., Haff, G. G., Ramsey, M. W., McBride, J., Triplett, T., Sands, W. A., ... \& Stone, M. H. (2012). Strength gains: Block versus daily undulating periodization weight training among track and field athletes. International Journal of Sports Physiology and Performance, 7(2), 161-169.

34. Rhea, M. R., \& Alderman, B. L. (2004). A meta-analysis of periodized versus nonperiodized strength and power training programs. Research quarterly for exercise and sport, 75(4), 413-422.

35. da Silva, F. P., Vilaça-Alves, J., de Souza, L. L., dos Santos, J. S., \& Figueiredo, T. (2016). Effects of Daily and Flexible Non-Linear Periodization on Maximal and Submaximal Strength, Vertical Jump and Speed Performance of Brazilian Army Skydivers. International Journal of Sports and Exercise Medicine, 2, 047.

36. Souza, E. O., Ugrinowitsch, C., Tricoli, V., Roschel, H., Lowery, R. P., Aihara, A. Y., ... \& Wilson, J. M. (2014). Early adaptations to six weeks of non-periodized and periodized strength training regimens in recreational males. Journal of Sports Science and Medicine, 13(3), 604-609.

37. Stone, M. H., Potteiger, J. A., Pierce, K. C., Proulx, C. M., O’bryant, H. S., Johnson, R. L., \& Stone, M. E. (2000). Comparison of the effects of three different weight-training programs on the one repetition maximum squat. The Journal of Strength and Conditioning Research, 14(3), 332-337.
38. Storer, T. W., Dolezal, B. A., Berenc, M. N., Timmins, J. E., \& Cooper, C. B. (2014). Effect of supervised, periodized exercise training vs. selfdirected training on lean body mass and other fitness variables in health club members. The Journal of Strength and Conditioning Research, 28(7), 1995-2006.

39. Strohacker, K., Fazzino, D., Breslin, W. L., \& Xu, $X$. (2015). The use of periodization in exercise prescriptions for inactive adults: A systematic review. Preventive Medicine Reports, 2, 385-396.

40. Tammam, A. H., \& Hashem, E. M. (2016). The Effect of Linear and Biweekly Non-Linear Periodized Resistance Training on Maximal Strength and Vertical Jump for Volleyball Players. Journal of Applied Sports Science, 6(1), 73-81.

41. Ullrich, B., Pelzer, T., \& Pfeiffer, M. (2018). Neuromuscular Effects to 6 Weeks of Loaded Countermovement Jumping with Traditional and Daily Undulating Periodization. The Journal of Strength and Conditioning Research, 32(3), 660-674.

42. Ullrich, B., Pelzer, T., Oliveira, S., \& Pfeiffer, M. (2016). Neuromuscular responses to short-term resistance training with traditional and daily undulating periodization in adolescent elite judoka. The Journal of Strength and Conditioning Research, 30(8), 2083-2099.

43. Williams, T. D., Tolusso, D. V., Fedewa, M. V., \& Esco, M. R. (2017). Comparison of periodized and non-periodized resistance training on maximal strength: a meta-analysis. Sports Medicine, 47(10), 2083-2100.
Примљен: 05.05.2019.

Прихваћен: 07.06. 2019.

Online објављен: 01.07.2019. 